\title{
The effect of industry nuances on the relationship between corporate governance and financial performance: Evidence from South African listed companies
}

\begin{tabular}{|c|c|}
\hline \multicolumn{2}{|c|}{ 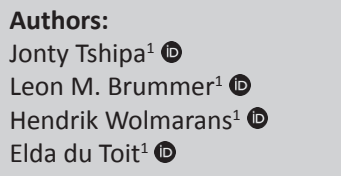 } \\
\hline \multicolumn{2}{|c|}{$\begin{array}{l}\text { Affiliations: } \\
{ }^{1} \text { Department of Financial } \\
\text { Management, Faculty of } \\
\text { Economic and Management } \\
\text { Sciences, University of } \\
\text { Pretoria, South Africa }\end{array}$} \\
\hline \multicolumn{2}{|c|}{$\begin{array}{l}\text { Corresponding author: } \\
\text { Jonty Tshipa, } \\
\text { tshipaj@gmail.com }\end{array}$} \\
\hline \multicolumn{2}{|c|}{$\begin{array}{l}\text { Dates: } \\
\text { Received: } 02 \text { June } 2017 \\
\text { Accepted: } 18 \text { Jan. } 2018 \\
\text { Published: } 18 \text { Apr. } 2018\end{array}$} \\
\hline \multicolumn{2}{|c|}{$\begin{array}{l}\text { How to cite this article: } \\
\text { Tshipa, J., Brummer, L.M., } \\
\text { Wolmarans, H. \& Du Toit E., } \\
\text { 2018, 'The effect of industry } \\
\text { nuances on the relationship } \\
\text { between corporate } \\
\text { governance and financial } \\
\text { performance: Evidence from } \\
\text { South African listed } \\
\text { companies', South African } \\
\text { Journal of Economic and } \\
\text { Management Sciences 21(1), } \\
\text { a1964. https://doi.org/ } \\
\text { 10.4102/sajems.v21i1.1964 }\end{array}$} \\
\hline \multicolumn{2}{|c|}{$\begin{array}{l}\text { Copyright: } \\
\text { (C) 2018. The Authors. } \\
\text { Licensee: AOSIS. This work } \\
\text { is licensed under the } \\
\text { Creative Commons } \\
\text { Attribution License. }\end{array}$} \\
\hline \multicolumn{2}{|l|}{ Read online: } \\
\hline 口品回 & $\begin{array}{l}\text { Scan this QR } \\
\text { code with your } \\
\text { smart phone or } \\
\text { mobile device } \\
\text { to read online. }\end{array}$ \\
\hline
\end{tabular}

Background: Premised on agency, resource dependence and stewardship theories, the study investigates empirically the existence of industry nuances in the relationship between corporate governance and financial performance of companies listed in the Johannesburg Stock Exchange.

Aims: The main objective of the study is to understand the relationship between internal corporate governance and company performance from the perspective of three distinct economic periods, as well as industry nuances, cognisant of endogeneity issues.

Setting: South Africa, as an emerging African market, offers an interesting research context in which the corporate governance and financial performance nexus can be examined empirically.

Method: A sample of 90 companies from the five largest South African industries, covering a 13-year period from 2002 to 2014 (1170 firm-year observations) was examined with three estimation approaches.

Results: Two key trends emerged from this study. First, the relationship between corporate governance and company performance differed from industry to industry. Second, the association between corporate governance and company performance also changes during steady and non-steady periods, which is an indication that the nexus is driven by the state of the global economy and the type of the industry.

Conclusion: Evidence from the study suggests that companies should be allowed to optimise rather than maximise their corporate governance options. This finding questioned the approach of the recently published King IV Code of Good Corporate Governance, which requires Johannesburg Stock Exchange-listed companies to 'apply and explain' as opposed to 'apply or explain' as pronounced by King III Code of Good Corporate Governance.

\section{Introduction}

The subject of corporate governance and corporate performance has been widely discussed and examined over the last two decades. This is so because compliance to corporate governance practices may influence the value of the firm (Tshipa et al. 2018a). The interest was heightened by corporate scandals such as Enron Corporation (Corp.), WorldCom Incorporated (Inc.) and Global Crossing Limited (Ltd). The collapse of these companies was supposedly a result of lapses in corporate governance (Ntim et al. 2012; Vinten 2002). As a result of these scandals, investors demanded reforms in both corporate structures and practices in exchange for their infusion of capital (Kakabadse \& Korac-Kakabadse 2002). Given the importance of corporate reforms, codes of corporate governance have attracted much attention from policy-makers and academics (Aguilera \& Cuervo-Cazurra 2009; Tshipa \& Mokoaleli-Mokoteli 2015). In Africa, South Africa was the first to develop a corporate governance code of best practices in 1994 (Mangena \& Chamisa 2008).

Recently, corporate governance has also been in the spotlight following the global financial crisis in 2007. Proponents of corporate governance argue that corporate governace provides a hedging mechanism during-crisis periods (Johnson et al. 2000; Tshipa et al. 2018b). On the other hand, critics of corporate governance attribute the global financial crisis squarely to corporate governance (Kirkpatrick 2009; Kumar \& Singh 2013).

Internal corporate governance attributes are expected to enhance company performance during normal economic times by effectively monitoring directors and ensuring that their interests 
and those of shareholders are in tandem (Afrifa \& Tauringana 2015). However, the cogency of such claims in abnormal economic times such as a financial crisis and for different types of industries has been questioned (Van Essen, Engelen \& Carney 2013).

The literature review indicates that research to date has an inconclusive record regarding good corporate governance and financial performance nexus. In the main, the lack of congruence has been credited to inadequate estimation methods, endogeneity inherent in corporate governance studies, economic periods, industry nuances and country differences (Tshipa et al. 2018b).

Therefore, the objective of the study is to understand the relationship between internal corporate governance and company performance from the perspective of three distinct economic periods, as well as industry nuances, cognisant of endogeneity issues. Distinct from other studies, both domestically and globally, a unique contribution of this study is the introduction of the industry-specific characteristics in the corporate governance and company performance relationship. This is because the one-size-fitsall approach may not capture the pertinent nuances in corporate governance across different industries (Ammann, Oesch \& Schmid 2013; Bruno \& Claessens 2010). Board characteristics should vary systematically across industries, either because of systematic differences in costs and benefits or because of some other commonality. For instance, in South Africa and globally, the size of the board in banks is twice as large as in other industries. This could be because the benefits reaped by banks from having a larger board may outweigh the increased communication and $\mathrm{CO}^{-}$ ordination costs, as highlighted in the study by Guest (2009). Therefore, by inference, it is expected that a larger board size as practised in banks should have a positive impact on company performance, irrespective of whether the proxy for company performance is accounting-based or market-based. Thus, the culmination of this study is the unique models for the association of corporate governance and company performance across all major South African industries. Comparing corporate governance among industries may lead to a more complete understanding of the subtleties that characterise the pervasive relationship between corporate governance and company performance across industries.

The period of this study is also unique, because it covers a relatively stable economic period before the financial crisis, a challenging and unstable period of time when the financial crisis materialised, and the aftermath of the financial crisis. In addition, the examination period of the study also covers the two corporate governance reforms in South Africa, King II in 2002 (Institute of Directors in Southern Africa 2002) and King III in 2009 (Institute of Directors in Southern Africa 2009), as well as the new Companies Act No. 71 of 2008 (Republic of South Africa 2008).

Literature also attributes the mixed results of corporate governance studies to potential endogeneity problems, which may significantly affect empirical corporate governance findings (Afrifa \& Tauringana 2015). In order to overcome the problem of endogeneity, this study employs several robust alternative specifications and estimation techniques for the analysis purposes, which include generalised methods of moments (GMM), two-stage least square (2SLS) and generalised least square (GLS) - the latter being the preferred estimator for this study. In addition, to reduce the potential endogeneity problem of simultaneity, which is found to be the most common endogeneity problem in corporate governance research (Larcker \& Rusticus 2010), the study lags all independent variables and investigates the association between changes in the independent variables and the dependent variable, taking a leaf from studies of Afrifa and Tauringana (2015), Tshipa et al. (2018b) and Mina, Lahr and Hughes (2013). Another big challenge in corporate governance empirical studies is the consideration of the dynamic nature of corporate governance, which is also considered as another source of endogeneity, namely dynamic endogeneity (Wintoki, Linck \& Netter 2012). To obviate this problem, and similar to the studies of Ayadi et al. (2015), Tshipa et al. (2018b) and Schultz, Tan and Walsh (2010), the effect of historical performance on current governance is considered when running the estimation models.

\section{Literature review}

This section discusses the relevant extant theories that attempt to link internal corporate governance structures and company performance. Theories underlying corporate governance have been drawn from a variety of disciplines, such as accounting, economics, finance and law (Durisin \& Puzone 2009). In this study, corporate governance is approached from a financial perspective, using a quantitative research methodology.

Similar to past studies (Aduda, Chogii \& Magutu 2013; Filatotchev \& Boyd 2009; Gartenberg \& Pierce 2017; Haniffa \& Hudaib 2006; Tshipa \& Mokoaleli-Mokoteli 2015; Wagana 2016; Tshipa et al. 2018a; Tshipa et al. 2018b), this study adopted a multiple theoretical orientation by combining several key theoretical perspectives, such as the agency, stewardship and resource dependence theories. The choice to use multiple theoretical perspectives is further motivated by the complementary nature of each theory. For instance, Cohen, Krishnamoorthy and Wright (2008) and Nelson et al. (2013) state that the agency theory on corporate governance should be complemented by additional perspectives such as the resource dependence, stewardship and stakeholder theories.

\section{Agency theory and corporate governance}

Agency theory-based research focuses largely on the relationship between board structure, control over management behaviour and strategic decision-making (Hafsi \& Turgut 2013). Agency theorists use the term corporate governance to interrogate the role of agents (managers) in fulfilling part of their contractual agreement with the principal (investor). The rudimentary view held by agency 
theorists of corporate governance is that at any given time, managers have self-interest and may not act to maximise shareholder returns, unless appropriate internal governance structures and controls (to monitor costs) are put in place to protect the interests of shareholders (Jensen \& Meckling 1976).

The agency framework suggests that corporate governance seeks to create and monitor the mechanisms that are put in place by shareholders to ensure that managers maximise shareholders' wealth by reducing agency loss (Adegbite, Amaeshi \& Amao 2012; Bonazzi \& Islam 2007). In the absence of strong corporate governance, management can use the additional control, not for long-term profitability, but instead, for their own personal wealth, status and goals (Gartenberg \& Pierce 2017).

Rebeiz (2015) describes the monitoring mechanisms as internal corporate governance structures. Sternberg (1998) asserts that the solitary role of corporate governance is to ensure that the company's financial and human capital resources, as well as assets, are directed so that it achieves the corporate mandate and objectives to shareholders' satisfaction. Accordingly, this simply means that agency theorists regard corporate governance as a mechanism to reduce agency loss. One such mechanism would be the deployment of the board of directors to act as monitors on behalf of investors.

The agency cost has gained prominence in the corporate governance literature as a result of the shortcomings of the stewardship theory (Rebeiz 2015). The agency theory states that chief executive officer (CEO) duality is bad for company performance as it compromises the monitoring and control of the CEO. However, in the last few years, many companies have converted from the dual CEO leadership structure to a non-dual structure, while a much smaller number of companies converted in the opposite direction (Moscu 2013). Hence, the problem of separating the roles of CEO and chairman of the board still seems unresolved. Interestingly, Yang and Zhao (2014) report that duality companies outperform non-duality companies by $3 \%$ to $4 \%$, which underscores the benefits of CEO duality in saving information costs and making speedy decisions.

One aspect in relation to the board internal structure is board activity (Arosa, Iturralde \& Maseda 2013). Board activity is defined as the frequency of board meetings in a year (Pamburai et al. 2015). The frequency of board meetings allows the board to be apprised of activities of the company and thus manage the agency relationship on behalf of the shareholders. The more frequent the meetings, the more detailed the control of the managers, and the greater the shareholder wealth (Arosa et al. 2013).

Board committees are the critical aspect of monitoring and, therefore, of the board. This is because critical processes and decision-making are not done at board level but at committee level, such as the nomination, audit and risk, and remuneration committees (Dalton et al. 1999). To this end, the establishment of board subcommittees has been strongly recommended as a suitable mechanism for improving corporate governance, by delegating specific tasks from the main board to a smaller group and harnessing the contribution of non-executive directors (Spira \& Bender 2004).

Essentially, the board delegates certain functions to these well-structured committees but without abdicating its own responsibilities. The purpose of establishing the committees is to alleviate its workload and to create committees that can function more effectively due to its composition consisting of a smaller grouping that can focus on key areas. Board committees enable directors to cope with two of the most important problems they face: the limited time they have available, and the complexity of the information with which they must deal (Dalton et al. 1999).

\section{Stewardship theory and corporate governance}

Stewardship theory arose from the seminar work by Donaldson and Davis (1991). Stewardship theorists trace their origins back to the human relations school of management (Hung 1998), the organisation theory (Clarke 1998), and sociology and psychology (Muth \& Donaldson 1998). Unlike the agency theory, the stewardship theory assumes that management are stewards whose interests are aligned with those of the owners (shareholders). Therefore, managers are motivated to make decisions that correspond with those of the shareholders that would maximise financial performance.

Corporate governance under the stewardship model is premised on the logic that managers work diligently to maximise shareholders' returns by virtue of being good stewards of corporate assets (Donaldson 1990). Therefore, this view leads to the assumption that management performance is not necessarily influenced by self-interest, but is more likely to be affected by the governance structural impediments that inhibit effective action (Davis, Schoorman \& Donaldson 1997).

Consequently, it could be argued that corporate governance, under the banner of the stewardship theory, is associated with 'structure' and hierarchy. This is corroborated by Whittred (1993), who asserts that corporate governance should provide facilitating and empowering structures to managers, which should enable managers to deliver superior returns to shareholders. Hence, the stewardship theory seeks to underscore the importance of combining the CEO and chairman roles to attain financial performance for the company. The stewardship theorists rationalise that in order to reduce agency costs, companies should not split the dual role of CEO and chairman (Abels \& Martelli 2013).

Proponents of the stewardship theory contend that better financial performance is likely to be associated with internal 
corporate governance practices that grant managers greater autonomy and power. The power should be centralised in the hand of the managers because of their intimate knowledge of the business (Rebeiz 2015). These powers include combining the positions of chairman and CEO (Donaldson \& Davis 1991). In this situation, power and authority are vested in a single person and there is no room for uncertainty as to who has authority or responsibility. It is believed that a single leadership structure, having combined the CEO and chairman roles, will assist the company to attain superior performance to the extent that the CEO exercises complete authority over the company and that the CEO's role is unambiguous and unchallenged.

\section{Resource dependence theory and corporate governance}

Nguyen, Locke and Reddy (2015) describe the resource dependence theory as an association between board characteristics and the company's critical resources, including aspects such as the companies' 'prestige and legitimacy'. The resource dependence theorists trace their origins to the school of sociology (Clarke 1998). It was developed by Pfeffer (1972) to emphasise that the board, particularly the composition of the non-executive directors, can provide the company with resources that can enhance company performance. First, the board and non-executive directors can offer essential resources, such as expert advice, requisite experience, independence and knowledge (Haniffa \& Cooke 2002). Second, they can provide reputation, credibility and critical business contacts (Haniffa \& Hudaib 2006). Finally, the board can facilitate access to business or political network, information and capital (Nicholson \& Kiel 2007).

Finally, the board provides a critical link to a company's external environment and significant stakeholders such as creditors, suppliers, customers and competitors. As a result, it has been argued that a greater level of links to the external environment is associated with better access to resources (Nicholson \& Kiel 2007). In other words, the resource dependence theory postulates that apart from the monitoring function, the board of directors also serves as a resource provider. Hillman and Dalziel (2003) refer to the ability of the board to solicit essential resources to the company as 'board capital'.

As stated by Hung (1998), companies depend on one another for access to valued resources. The resource dependence theory posits that companies are interrelated and depend on the external environment for survival. According to Pfeffer (1972), the board of directors could be seen as the requisite link between the company and the external environment.

A board's ability to fulfil this function is linked to a director's connections to other entities - that is, the board interlocks as the latter is frequently regarded as a conduit between companies (Shropshire 2010). When a member of a board of directors also sits on other boards of directors, a director interlock is created. Hence, Hung (1998) states that there are indeed benefits to director interlocking. This could impact financial performance positively.

Proponents of diversity in corporate boardrooms usually base their arguments on agency, resource dependence, human capital and signalling theories (Taljaard, Ward \& Muller 2015). First, the agency theory states that diversity in the boardroom increases board independence and improves executive monitoring (Van der Walt \& Ingley 2003). Second, it brings diversity in ideas, perspectives, experiences and business knowledge to the decisionmaking process in boardrooms (Baranchuk \& Dybvig 2009). This can better aid appreciation of the intricacies of the external environment and global marketplace. Board diversity can also increase creativity and innovation in boardrooms due to diversity in cognitive abilities, which can also facilitate effective decision-making (Carter, Simkins \& Simpson 2003).

\section{Research hypothesis}

Accordingly, the hypotheses for this study are on the effect of board size, board independence, board activity, board diversity, leadership structure and presence of key board committees on financial performance. The foregoing variables are all internal structures and processes within the control of the company's shareholders and the board of directors. Brown, Beekes and Verhoeven (2011) refer to these as internal corporate governance structures. The focus of this study is thus on the impact of internal corporate governance structures on financial performance. The corporate governance variables chosen were based on prior studies as well as the Johannesburg Stock Exchange (JSE) Listing Requirements as recommended by King III. The independent variables were: board size, board independence, board committees, board diversity, board activity and leadership structure.

Therefore, the following research hypotheses are formulated:

$\mathbf{H}_{1 \mathrm{~A}}$ : There is a positive significant relationship between board size and financial performance.

$\mathbf{H}_{2 \mathrm{~A}}$ : There is a positive significant relationship between board independence and financial performance

$\mathbf{H}_{3 \mathrm{~A}}$ : There is a positive significant relationship between the presence of key internal board committees and financial performance.

$\mathbf{H}_{4 \mathrm{~A}}$ : There is a positive significant relationship between board activity and financial performance

$\mathbf{H}_{5 \mathrm{~A}}$ : There is a positive significant relationship between board diversity and financial performance.

$\mathbf{H}_{6 \mathrm{~A}}$ : There is positive significant relationship between leadership structure and financial performance.

\section{Methods}

The data used in the study to investigate the impact of corporate governance on company performance was sourced 
from the INET BFA database. The study ended with a sample of 90 companies from five major industries, covering the period 2002 to 2014. This number of companies and the period of examination translated into 1170 firm-year observations. The examination period of 2002 to 2014 was critical to the study because during this period, King II (Institute of Directors in Southern Africa 2002), King III (Institute of Directors in Southern Africa 2009) and the Companies Act No. 71 of 2008 (Republic of South Africa 2008) were implemented. In addition, the global financial crisis occurred. Consequently, companies that made the sample needed to have been exposed to all the domestic reforms as well as the global financial crisis.

To this end, similar to the study of Vintilă and Gherghina (2013), the unbalanced multiple regression panel data analysis was used as the main tool. Three estimation methods, the generalised method of moments, two-stage least squares and generalised least squares (GLS) fixed effects, were considered. Similar to the study of Habib (2016), among others, GLS emerged as the preferred statistical method based on the explanatory power and the goodness of fit.

\section{Model specification}

As mentioned in the 'Introduction', one of the most daunting tasks in corporate governance empirical studies is dealing with the endogeneity of corporate governance independent variables. Being oblivious to endogeneity may result in spurious and unreliable causality inferences (Roberts \& Whited 2013).

In light of this, Wintoki et al. (2012) and Tshipa et al. (2018b) recommend that the appropriate empirical model for the corporate governance and performance nexus should be a dynamic model instead of a static model, in which lagged performance is used as one of the independent variables. Therefore, this study also adopts a dynamic modelling approach to investigate the relationship between corporate governance and company performance. By doing so, this study responds to recent calls by Arora and Sharma (2016), Nguyen, Locke and Reddy (2014), Nguyen et al. (2015), Schultz et al. (2010) and Waweru (2014) to use dynamic panel models in corporate governance and finance studies.

In view of the preceding, the model specification for this study is as follows:

$\mathrm{Y}_{\mathrm{it}}=\alpha_{0}+\alpha_{1} \mathrm{Y}_{\mathrm{it}-1}+\beta_{1} \mathrm{BS}_{\mathrm{it}}+\beta_{2} \mathrm{BI}_{\mathrm{it}}+\beta_{3} \mathrm{BC}_{\mathrm{it}}+\beta_{4} \mathrm{BA}_{\mathrm{it}}+\beta_{5} \mathrm{BD}_{\mathrm{it}}+\beta_{6} \mathrm{LS}_{\mathrm{it}}$

$+\beta_{7} \mathrm{AGE}_{\mathrm{it}}+\beta_{8} \mathrm{SIZE}_{\mathrm{it}}+\beta_{9} \mathrm{LEV}_{\mathrm{it}}+\beta_{10} \mathrm{GROWTH}_{\mathrm{it}}+\varepsilon_{\mathrm{it}}$ [Eqn 1]

where $Y_{i t}$ measures company performance indicators, return on asset (ROA) and Tobin's $Q, Y_{i t-1}$ represents the performance lag of one year. $\mathrm{BS}_{i t^{\prime}}, \mathrm{BI}_{i t^{\prime}}, \mathrm{BC}_{i t^{\prime}}, \mathrm{BA}_{i t}, \mathrm{BD}_{i t}$ and $\mathrm{LS}_{i t}$ are corporate governance variables, namely board size, board independence, presence of key board committees, board diversity and leadership structure respectively, of company $i$ at period $t$. AGE, SIZE, Leverage (LEV) and Growth $(\mathrm{G})$ are used as control variables for company age, company size, leverage and growth prospects. The intercept is $\alpha_{0}$, the error term is $\varepsilon_{i t}$ and $\alpha_{1}$ is the unknown estimated coefficient. The following models are thus used for the entire period (20022014), pre-financial crisis (2005-2007), during the crisis (2008-2010) and post-financial crisis (2011-2013), for the whole sample as well as for each industry.

\section{Model 1}

Tobin's $\mathrm{Q}=\alpha_{0}+$ Tobin's $\mathrm{Q}_{\mathrm{it}-1}+\beta_{1} \mathrm{BS}_{\mathrm{it}}+\beta_{2} \mathrm{BI}_{\mathrm{it}}+\beta_{3} \mathrm{BC}_{\mathrm{it}}$

$$
\begin{aligned}
& +\beta_{4} \mathrm{BA}_{\mathrm{it}}+\beta_{5} \mathrm{BD}_{\mathrm{it}}+\beta_{6} \mathrm{LS}_{\mathrm{it}}+\beta_{7} \mathrm{AGE}_{\mathrm{it}} \\
& +\beta_{8} \mathrm{SIZE}_{\mathrm{it}}+\beta_{9} \mathrm{LEV}_{\mathrm{it}}+\beta_{10} \mathrm{GROWTH}_{\mathrm{it}}+\varepsilon_{\mathrm{it}}
\end{aligned}
$$

\section{Model 2}

$$
\begin{aligned}
\mathrm{ROA} & =\alpha_{0}+\mathrm{ROA}_{\mathrm{it}-1}+\beta_{1} \mathrm{BS}_{\mathrm{it}}+\beta_{2} \mathrm{BI}_{\mathrm{it}}+\beta_{3} \mathrm{BC}_{\mathrm{it}}+\beta_{4} \mathrm{BA}_{\mathrm{it}} \\
& +\beta_{5} \mathrm{BD}_{\mathrm{it}}+\beta_{6} \mathrm{LS}_{\mathrm{it}}+\beta_{7} \mathrm{AGE}_{\mathrm{it}}+\beta_{8} \mathrm{SIZE}_{\mathrm{it}}+\beta_{9} \mathrm{LEV}_{\mathrm{it}} \\
& +\beta_{10} \mathrm{GROWTH}_{\mathrm{it}}+\varepsilon_{\mathrm{it}}
\end{aligned}
$$

As already mentioned, for corporate governance measures, the study considers board size, board independence, board committees, board activity, board diversity and leadership structure, while the control variables are company age, company size, leverage and growth prospects. Data for the performance measures, ROA and Tobin's $Q$ are not manually calculated but retrieved from the INET BFA database. INET BFA database is South Africa's leading provider of financial data feeds as well as organisation information including annual reports and financial statements (Bussin \& Modau 2015). The construction of these variables for the empirical analysis is presented in Table 1. Definitions of variables are largely adopted from existing literature with the aim of making a meaningful comparison with earlier empirical studies.

\section{Results}

The following section discusses the descriptive statistics and preliminary data analysis, as well as the regression results for each of the five industries. For ease of comparison, in each industry, two tables are presented for all hypotheses. The first table shows the hypotheses and Tobin's Q and the second table presents the hypotheses and ROA. One of the objectives, as highlighted in the 'Introduction', is to develop a corporate governance and performance model for each industry. In the light of this objective, the analysis for each industry culminates in a customised corporate governance model for ROA and Tobin's Q (also see Appendix 1).

\section{Preliminary data analysis}

Before conducting the regression analysis, various preliminary tests are conducted (Haniffa \& Hudaib 2006; Pamburai et al. 2015). The following subsection discusses the assumptions of the ordinary least squares regression method to determine which estimation technique is appropriate for the study. These assumptions include normality, linearity, homoscedasticity, multicollinearity, auto-correlation and presence of outliers. 
TABLE 1: Description of variables used in the study.

\begin{tabular}{|c|c|c|c|}
\hline Abbreviation $^{\mathrm{a}}$ & Variables $^{b}$ & Definitions of variables $^{c}$ & Source $^{d}$ \\
\hline \multicolumn{4}{|l|}{ CG } \\
\hline BS & Board size & The total number of directors sitting on the board. & Annual report \\
\hline $\mathrm{BI}$ & Board independence & Percentage of independent non-executive directors. & Annual report \\
\hline BC & Board committees & $\begin{array}{l}\text { A dummy variable that takes a value of } 1 \text { if the company has nominations, remuneration and to audit } \\
\text { committees, otherwise } 0 \text {. }\end{array}$ & Annual report \\
\hline BA & Board activity & The number of times the board of directors meets in a financial year. & Annual report \\
\hline $\mathrm{BD}$ & Board diversity & Percentage of non-white females on a board. & \\
\hline LS & Leadership structure & $\begin{array}{l}\text { A dummy variable that takes the value of } 1 \text { if the positions of CEO and chairman are held by two } \\
\text { different persons, otherwise } 0 \text {. }\end{array}$ & Annual report \\
\hline \multicolumn{4}{|l|}{ Control } \\
\hline Age & Company age & Present year minus incorporation year. & INET BFA database \\
\hline Size & Company size & Natural logarithm of the book value of total assets. & INET BFA database \\
\hline Lev & Leverage & Borrowing divided by total assets. & INET BFA database \\
\hline Growth & Growth prospects & Ratio of capital expenditure to total assets. & INET BFA database \\
\hline$Y_{i t-1}$ & Lagged dependent & One-year lag of company performance. & INET BFA database \\
\hline ROA & Return on assets & Accounting-based measure. & INET BFA database \\
\hline Tobin's Q & Tobin's Q & Market-based measure. & INET BFA database \\
\hline
\end{tabular}

Source: INET BFA, 2016, Research domain. Software and database. Johannesburg, South Africa.

CG, Corporate governance; BS, board size; BI, board independence; BC, board committees; BA, board activity; BD, board diversity; LS, leadership structure; Lev, leverage; $\mathrm{Y}_{\mathrm{it}-1,{ }^{\prime}}$ Lagged dependent; ROA, return on asset.

a, presents the abbreviation used in Equation $1 ;^{b}$, reports the variables in full; ${ }^{c}$, defines the variables; ${ }^{d}$, provides the data source.

\section{Assumption of auto-correlation}

The Durbin Watson statistic indicates independence between the residuals when the statistic encompasses values between 1.5 and 2.5 (Diebold 2016; Greene 2002), where values near 2 indicate the lack of auto-correlation (Schwarz 2015). In this study, such a condition is met for all dependent variables, which indicates that the data are not autocorrelated.

\section{Panel data unit root test}

For this study, the Levin, Lin and Chut test is applied and the test gives absence of unit roots by rejecting the null hypothesis. Using variables without taking the first difference in the estimation model may give spurious results. Therefore, the study uses the first difference to obviate unit root.

\section{Assumption of normality}

An analysis of the skewness and kurtosis indicates that most of the variables used in this study do not meet the assumption of normality - only the board committee independent variable meets the assumption of normality, with a skewness of 0.625 and kurtosis of 1.39. Consequently, the non-normal distribution of the variables indicates that an ordinary least squares regression is not appropriate for the study. An alternative is to use a GLS model, which will provide more robust estimates (Olsson et al. 2000; Wahba 2015).

\section{Assumption of outliers}

A box-plot was conducted to identify the presence of outliers in the data. There are a few outliers, though not significant. The presence of outliers may give rise to heteroskedasticity (Gujarati 2004). Unequal variances may exist due to the presence of outliers and skewness. A GLS regression with a robust standard error was carried out to test the research hypotheses.
The GLS method is applied when the variances of the observations are unequal or in the presence of heteroskedasticity (Gujarati 2004). While the ordinary least squares method assigns equal weight or importance to each observation and does not use information relating to the unequal variability of the dependent variable, GLS can produce more accurate estimators in the presence of outliers or heteroskedasticity, because it clearly takes such information into account (Aslam \& Pasha 2007; Gujarati 2004).

\section{Assumption of multicollinearity}

To detect this problem, the Pearson correlation matrix is used to test the multicollinearity problem (Sheikh \& Wang 2012). Similar to the studies of Mohammed, Che-Ahmad and Aljaaidi (2012) and Pamburai et al. (2015), the fact that the correlation coefficients are below the 0.8 threshold indicates that multicollinearity is not a problem in this study.

Further, similar to the studies of Muchemwa, Padia and Callaghan (2016), Pamburai et al. (2015) and RodriguezFernandez, Fernandez-Alonso and Rodriguez-Rodriguez (2014), in addition to the correlation matrix, this study also assesses the variance inflation factors to check the level of multicollinearity for each dependent variable against all six independent variables. Chatterjee and Hadi (2012) posit that a value of variance inflation factors larger than 10 should be considered an indication of the presence of multicollinearity. The results indicate that multicollinearity is not a problem because all variance inflation factors values are well below the cut-off point of 10 as stated by Chatterjee and Hadi (2012).

\section{Selection of the appropriate estimation method for the study}

Based on displaying the smallest residuals $\left(\mathrm{S}^{2}\right)$ and highest adjusted $\mathrm{R}^{2}$, as well as the F-value as guided by the studies of Rad (2014) and Tshipa et al. (2018b), GLS estimator 
emerged as the estimation method which best fits the model (more so than generalised method of moments and two-stage least squares). This estimation technique allows for potential sources of endogeneity inherent in the corporate governance and company performance relationship, including dynamic endogeneity, simultaneity and unobserved time-invariant heterogeneity across companies.

\section{Corporate governance and financial performance nexus in the financials industry}

Appendix 2 presents the descriptive statistics for the financials industry. Notably, the descriptive statistics reveal that both performance measures, Tobin's Q (ROA) dropped from 1.544 (2.355) (pre-crisis) to 0.984 (2.304) (during the crisis) but recovered again after the crisis to 1.097 (3.578). This demonstrates the significant decline in company performance as a result of the financial crisis. The recovery after the crisis indicates the resilience of the financials industry to the aftermath of the global financial crisis. Notably, ROA was higher (3.578) after the crisis than it was before the crisis (2.355) and during the crisis (2.304), implying that the increased corporate governance compliance levels may have acted as a hedging mechanism for the South African financials companies as concluded in the study of Tshipa et al. (2018b).

The compliance levels in terms of all corporate governance increased during the transition from the pre-crisis to the crisis period. On average, financials companies had 11.1 board members pre-crisis and 12.4 during the crisis, with $16 \%$ representation of non-white women before the crisis and $21 \%$ after the crisis. There were $45.9 \%$ of independent nonexecutive directors pre-crisis, which increased to $49.4 \%$ during the crisis. The number of companies having all three board committees increased from $40 \%$ to $60 \%$ during the crisis. On average, the board met 5.05 times pre-crisis and 5.18 times during the crisis. Companies that have separated the roles of CEO and chairman increased from $90 \%$ to $95 \%$ during the crisis.

For the pre-crisis period, the size of the board, the presence of board committees and board diversity all had a positive impact on Tobin's Q, while board independence and leadership structure had a negative influence. However, during the crisis period, board committees, board activity and leadership had a positive influence on company performance. After the financial crisis, board independence, board committees and board diversity had an inverse relationship, while board size had a positive nexus with Tobin's Q.

Overall, all corporate governance variables, except board independence had a positive influence on Tobin's $Q$ in varying periods. This indicates that corporate governance is contingent on economic periods, even during a crosssectional analysis.

With regard to ROA, before the crisis period, board committees, board activities and leadership structure had a positive impact, while the size of the board, board independence and board diversity had a negative impact before the crisis. During the crisis, the signs of the board size and board diversity changed from negative to positive, indicating that the increase noted in both parameters yielded positive results. Similar to Erkens, Hung and Matos (2012), this study found an inverse relationship between the proportion of independent directors and company performance. This indicates that companies that have more independent directors perform worse than their counterparts during the crisis period. After the crisis period, contrary to Orazalin, Mahmood and Lee (2016), who found a negative relationship between board size and ROA for Russian banks, this study documents a positive association.

Similar to Tobin's Q, all corporate governance variables but board independence had a positive influence on ROA in varying periods. This indicates that regardless of the performance measure used, the proportion of independent non-executive directors had a detrimental effect on the financial wellbeing of the financials industry. Therefore, the corporate governance-performance model specific for the financials industry is as follows (see Appendix 1):

\section{Pre-crisis period}

$\begin{aligned} \mathrm{ROA} & =-0.5586(\mathrm{BS})-6.3982(\mathrm{BI})+4.4321(\mathrm{BC})+0.1021(\mathrm{BA}) \\ & -15.268(\mathrm{BD})+4.7332(\mathrm{LS})\end{aligned}$

Tobin's $\mathrm{Q}=0.0751(\mathrm{BS})-1.0817(\mathrm{BI})+0.4614(\mathrm{BC})$

$$
-0.0527(\mathrm{BA})+0.7191(\mathrm{BD})-0.7126(\mathrm{LS})
$$

\section{During-crisis period}

$\mathrm{ROA}=0.4090(\mathrm{BS})-11.355(\mathrm{BI})+3.8661(\mathrm{BD})+3.0567(\mathrm{LS})$

Tobin's $\mathrm{Q}=0.1341(\mathrm{BC})+0.0180(\mathrm{BA})+0.2851(\mathrm{LS})$

\section{Post-crisis period}

$\mathrm{ROA}=0.1126(\mathrm{BS})+0.6882(\mathrm{BC})-0.2617(\mathrm{BA})-5.6558(\mathrm{BD})$

Tobin's $\mathrm{Q}=0.0155(\mathrm{BS})-0.1213(\mathrm{BI})-0.0832(\mathrm{BC})-0.3182(\mathrm{BD})$

\section{Corporate governance and financial performance nexus in the consumer services industry}

While most industries experienced a drop in terms of performance metrics, in contrast, the consumer services industry seems to have benefitted from the financial crisis (see Appendix 3). Tobin's Q increased by $92 \%$ from 1.57 (precrisis) to 3.01 (post-crisis). Similarly, ROA increased by $24 \%$ from 15.96 (pre-crisis) to 19.81 (post-crisis).

The compliance levels also increased during the transitional periods, with the exception of the board activities. Contrary to the expectations that the board would meet frequently during-crisis periods, in this industry, the board met fewer times during the crisis period (4.28 times less) than in other periods. 
TABLE 2: Regression results of the impact of corporate governance attributes on Tobin's $Q$ and Return on Asset for the financials industry.

\begin{tabular}{|c|c|c|c|}
\hline Panel & CG variables $^{\mathrm{a}}$ & Tobin's $Q^{b}$ & ROA $^{c}$ \\
\hline \multirow{11}{*}{$\begin{array}{l}\text { A: Pre-crisis } \\
\text { (2005-2007) }\end{array}$} & Perf $(-1)$ & $(0.5505)^{* * *}$ & $(0.6800)^{* * *}$ \\
\hline & BS & $(0.0751)^{* * *}$ & $(-0.5586)^{* * *}$ \\
\hline & $\mathrm{BI}$ & $(-1.0817)^{* * *}$ & $(-6.3982) * * *$ \\
\hline & $\mathrm{BC}$ & $(0.4614)^{* * *}$ & $(4.4321)^{* * *}$ \\
\hline & BA & $(-0.0527) * * *$ & $(0.1021)^{* *}$ \\
\hline & $\mathrm{BD}$ & $(0.7191)^{* * *}$ & $(-15.2685)^{* * *}$ \\
\hline & LS & $(-0.7126)^{* * *}$ & $(4.7332)^{* * *}$ \\
\hline & Weighted stats: & & \\
\hline & Adjusted $R^{2}$ & 0.9976 & 0.9971 \\
\hline & Prob (F-statistic) & 0.0000 & 0.0000 \\
\hline & Durbin Watson & 1.7089 & 1.4907 \\
\hline \multirow{12}{*}{$\begin{array}{l}\text { B: During } \\
\text { the crisis } \\
\text { (2008-2010) }\end{array}$} & CG variables & Tobin's $Q^{b}$ & $\mathrm{ROA}^{\mathrm{c}}$ \\
\hline & Perf $(-1)$ & $(0.6737)^{* * *}$ & $(0.5336)^{* * *}$ \\
\hline & BS & $\mathrm{N} / \mathrm{S}$ & $(0.4090) * * *$ \\
\hline & $\mathrm{BI}$ & $\mathrm{N} / \mathrm{S}$ & $(-11.3551) * * *$ \\
\hline & $B C$ & $(0.1341)^{* * *}$ & $\mathrm{~N} / \mathrm{S}$ \\
\hline & BA & $(0.0180)^{* * *}$ & $\mathrm{~N} / \mathrm{S}$ \\
\hline & $\mathrm{BD}$ & $\mathrm{N} / \mathrm{S}$ & $(3.8661)^{* * *}$ \\
\hline & LS & $(0.2851)^{* * *}$ & $(3.0567)^{* * *}$ \\
\hline & Weighted stats: & & \\
\hline & Adjusted $R^{2}$ & 0.9401 & 0.9995 \\
\hline & Prob (F-statistic) & 0.0000 & 0.0000 \\
\hline & Durbin Watson & 1.4097 & 2.1999 \\
\hline \multirow{12}{*}{$\begin{array}{l}\text { C: After the } \\
\text { crisis period } \\
\text { (2011-2013) }\end{array}$} & CG variables & Tobin's $Q^{b}$ & $\mathrm{ROA}^{\mathrm{c}}$ \\
\hline & Perf $(-1)$ & $(0.9928)^{* * *}$ & $(0.5237)^{* * *}$ \\
\hline & BS & $(0.0155) * * *$ & $(0.1126)^{* * *}$ \\
\hline & $\mathrm{BI}$ & $(-0.1213)^{* * *}$ & $N / S$ \\
\hline & $\mathrm{BC}$ & $(-0.0832)^{* *}$ & $(0.6882)^{* * *}$ \\
\hline & BA & $\mathrm{N} / \mathrm{S}$ & $(-0.2617)^{* * *}$ \\
\hline & $\mathrm{BD}$ & $(-0.3182) * * *$ & $(-5.6558) * * *$ \\
\hline & LS & $\mathrm{N} / \mathrm{S}$ & $N / S$ \\
\hline & Weighted stats: & & \\
\hline & Adjusted $R^{2}$ & 0.9988 & 0.9804 \\
\hline & Prob (F-statistic) & 0.0000 & 0.0000 \\
\hline & Durbin Watson & 1.8893 & 1.8314 \\
\hline
\end{tabular}

Note: Table 2 shows regression results of the impact of corporate governance attributes on Tobin's $Q$ and ROA for the financials industry. The abbreviations and definitions of the independent and control variables presented in this table are contained in Table 1. Panel A is for the pre-crisis period (2005-2007), Panel B is for the crisis period (2008-2010) and Panel C is for the post-crisis period (2011-2013). Coefficients are in parentheses and the table l variables, which are reported in Appendix 2 .

$\mathrm{N} / \mathrm{S}$, no statistical significance; ROA, return on asset; CG, corporate governance; Perf (-1) performance lag; $\mathrm{BS}$, board size; $\mathrm{BI}$, board independence; $\mathrm{BC}$, board committees; $\mathrm{BA}$, board activity; BD, board diversity; LS, leadership structure.

[*, significant at the 0.10 level]; **, significant at the 0.05 level; ***, significant at the 0.01 level. a, Column 1 shows the corporate governance variables; ${ }^{\text {b }}$ Column 2 shows the impact of corporate governance on Tobin's Q; ${ }^{c}$, Column 3 presents the impact of corporate governance on ROA.

The results show that board size had a positive impact on Tobin's Q regardless of the economic period. This supports the agency theory, namely that larger boards make more effort to reach consensus and reduce uncertainty during a recession period. In respect of ROA, during normal times (pre- and post-crisis), board size had a positive impact on ROA and inverse relationship during the abnormal times (crisis period). Regardless of the performance measure used, the proportion of independent non-executive directors, convening board meetings at least four times a year and separating the roles of chairman and CEO generated negative accounting and market returns for companies in the consumer services industry. Therefore, the corporate governance and performance model specific for the consumer services industry is as follows (see Appendix 1):
TABLE 3: Regression results of the impact of corporate governance attributes on Tobin's $Q$ and Return on Asset for the consumer services industry.

\begin{tabular}{|c|c|c|c|}
\hline Panel & CG variables $^{\mathrm{a}}$ & Tobin's $Q^{b}$ & ROA $^{c}$ \\
\hline \multirow{11}{*}{$\begin{array}{l}\text { A: Pre-crisis } \\
\text { (2005-2007) }\end{array}$} & Perf (-1) & $(0.2785)^{* * *}$ & $(0.4136)^{* * *}$ \\
\hline & BS & $(0.0827)^{* * *}$ & $(0.6181)^{* * *}$ \\
\hline & $\mathrm{BI}$ & $\mathrm{N} / \mathrm{S}$ & $(-2.2630) * * *$ \\
\hline & $\mathrm{BC}$ & $(0.2169)^{* *}$ & $(3.3026) * * *$ \\
\hline & BA & $(-0.1948) * * *$ & $(-1.8567)^{* *}$ \\
\hline & $\mathrm{BD}$ & $(3.0690)^{* * *}$ & $(17.835)^{* * *}$ \\
\hline & LS & $(-0.6286) * * *$ & $(-9.0618)^{* * *}$ \\
\hline & Weighted stats: & & \\
\hline & Adjusted $R^{2}$ & 0.9851 & 0.9955 \\
\hline & Prob ( $F$-statistic) & 0.0000 & 0.0000 \\
\hline & Durbin Watson & 1.9305 & 1.2320 \\
\hline \multirow{12}{*}{$\begin{array}{l}\text { B: During } \\
\text { the crisis } \\
\text { (2008-2010) }\end{array}$} & CG variables & Tobin's $Q^{b}$ & $\mathrm{ROA}^{\mathrm{c}}$ \\
\hline & Perf (-1) & $(0.6684)^{* * *}$ & $(1.0158)^{* * *}$ \\
\hline & BS & $(0.025)^{* *}$ & $(-0.1800) * * *$ \\
\hline & $\mathrm{BI}$ & $(-1.227)^{* * *}$ & $(-5.0278) * * *$ \\
\hline & $\mathrm{BC}$ & $(0.4653)^{* * *}$ & $(1.6685)^{* *}$ \\
\hline & BA & $(-0.1109) * * *$ & $(-0.4497)^{*}$ \\
\hline & $\mathrm{BD}$ & $(1.0601)^{* * *}$ & $(-13.6565) * * *$ \\
\hline & LS & $(-0.6744) * * *$ & $(-5.6960) * * *$ \\
\hline & Weighted stats: & & \\
\hline & Adjusted $R^{2}$ & 0.9881 & 0.9974 \\
\hline & Prob ( $F$-statistic) & 0.0000 & 0.0000 \\
\hline & Durbin Watson & 1.6674 & 1.6952 \\
\hline \multirow{12}{*}{$\begin{array}{l}\text { C: After the } \\
\text { crisis period } \\
\text { (2011-2013) }\end{array}$} & CG variables & Tobin's $Q^{b}$ & ROA $^{c}$ \\
\hline & Perf (-1) & $(1.0242)^{* * *}$ & $(0.9511)^{* * *}$ \\
\hline & BS & $(0.1394)^{* * *}$ & $(0.6494)^{* * *}$ \\
\hline & $\mathrm{BI}$ & $(-0.8561) * * *$ & $\mathrm{~N} / \mathrm{S}$ \\
\hline & $\mathrm{BC}$ & $(-0.3502)^{* * *}$ & $(-1.5451)^{* * *}$ \\
\hline & $\mathrm{BA}$ & $(-0.2363)^{*}$ & $(-1.1409)^{* * *}$ \\
\hline & $\mathrm{BD}$ & $\mathrm{N} / \mathrm{S}$ & $(7.7731)^{* * *}$ \\
\hline & LS & $(-0.1999) * * *$ & $(-2.4317)^{* *}$ \\
\hline & Weighted stats: & & \\
\hline & Adjusted $R^{2}$ & 0.9992 & 0.9991 \\
\hline & Prob ( $F$-statistic) & 0.0000 & 0.0000 \\
\hline & Durbin Watson & 1.9158 & 1.9484 \\
\hline
\end{tabular}

Note: Table 3 shows regression results of the impact of corporate governance attributes on Tobin's $Q$ and ROA for the consumer services industry. Column 1 shows the corporate Tobin's Q and ROA for the consumer ser governance variables. Colum 2 shows the impact of corporate governance on Tobin's $Q$ while Column 3 presents the impact of corporate governance on ROA. The abbreviations and definitions of the independent and control variables presented in this table are contained in 2010) and Panel $C$ is for the post-crisis period (2011-2013). Coefficients are in parenthese and the table excludes control variables, which are reported in Appendix 2.

$\mathrm{N} / \mathrm{S}$, no statistical significance; ROA, return on asset; CG, corporate governance; Perf $(-1)$, performance lag; $\mathrm{BS}$, board size; $\mathrm{BI}$, board independence; $\mathrm{BC}$, board committees; $\mathrm{BA}$, board activity; BD, board diversity; LS, leadership structure.

***, significant at the 0.01 level; **, significant at the 0.05 level; *, significant at the 0.10 level. a, Column 1 shows the corporate governance variables; ${ }^{b}$, Column 2 shows the impact of corporate governance on Tobin's $Q ;{ }^{c}$, Column 3 presents the impact of corporate governance on ROA.

\section{Pre-crisis period}

$$
\begin{aligned}
\mathrm{ROA} & =0.6181(\mathrm{BS})-2.2630(\mathrm{BI})+3.3026(\mathrm{BC})-1.8567(\mathrm{BA}) \\
& +17.835(\mathrm{BD})-9.0618(\mathrm{LS})
\end{aligned}
$$

Tobin's $\mathrm{Q}=0.0827(\mathrm{BS})+0.2169(\mathrm{BC})-0.1948(\mathrm{BA})$

$$
+3.0690(\mathrm{BD})-0.6286(\mathrm{LS})
$$

\section{During-crisis period}

$\begin{aligned} \mathrm{ROA} & =-0.1800(\mathrm{BS})-5.0278(\mathrm{BI})+1.6685(\mathrm{BC})-13.656(\mathrm{BD}) \\ & -5.6960(\mathrm{LS})\end{aligned}$

Tobin's $\mathrm{Q}=0.0252(\mathrm{BS})-1.2270(\mathrm{BI})+0.4653(\mathrm{BC})-0.1109(\mathrm{BA})$ $+1.0601(\mathrm{BD})-0.6744(\mathrm{LS})$ 


\section{Post-crisis period}

$\mathrm{ROA}=0.6494(\mathrm{BS})-1.5451(\mathrm{BC})-1.1409(\mathrm{BA})+7.7731(\mathrm{BD})$

$$
-2.4317(\mathrm{LS})
$$

Tobin's $\mathrm{Q}=0.1394(\mathrm{BS})-0.8561(\mathrm{BI})-0.3502(\mathrm{BC})-0.2363(\mathrm{BD})$

$$
-0.1999(\mathrm{LS})
$$

\section{Corporate governance and financial performance nexus in the consumer goods industry}

Appendix 4 reveals that while Tobin's Q declined by $28 \%$ from 3.11 (pre-crisis) to 2.21 (post-crisis), ROA did not suffer the same feat as it increased by $12 \%$ from 15.96 (pre-crisis) to 17.8 (post-crisis). There was an increase in corporate governance compliance levels in all respects. It is noteworthy that after the global crisis, in all companies in this industry, the positions of CEO and chairman were occupied by different people. Notably, board committees had a positive influence on Tobin's $Q$ throughout the three economic periods, supporting the agency theory that constant monitoring reduces agency costs and improves performance. The committees are important to ensure that the financial procedure is carried out well and the directors are appropriately compensated, hence mitigating any agency problems and improving performance (Fauzi \& Locke 2012).

All corporate governance variables except for leadership structure had a positive impact on Tobin's $Q$ in varying periods. This implies that separating the roles of chairman and CEO does not generate any market returns in any intervening periods.

Considering ROA, board size, board activity and board diversity had a positive correlation with the performance parameter, pre-crisis period. Notably, board diversity had a positive influence on the accounting-based measure in all economic periods. The positive relationship between board diversity and financial performance is predicted by both the agency theory and the resource dependence theory (Nguyen et al. 2014). Notably, all corporate governance variables except board independence are positively correlated to the accounting returns. The inverse relationship between board independence and ROA supports the stewardship theory, namely that management have the requisite experience and skills more than independent non-executive directors to generate positive returns for the company. Therefore, the corporate governance and performance model specific for the consumer goods industry is as follows (see Appendix 1):

\section{Pre-crisis period \\ $\mathrm{ROA}=0.6755(\mathrm{BS})-4.4861(\mathrm{BI})+0.4983(\mathrm{BA})+12.748(\mathrm{BD})$ $-7.1772(\mathrm{LS})$ \\ Tobin's $\mathrm{Q}=0.1706(\mathrm{BS})+1.7962(\mathrm{BC})-0.2575(\mathrm{BA})-9.8164(\mathrm{BD})$}

\section{During-crisis period}

$\mathrm{ROA}=-4.9820(\mathrm{BC})+13.998(\mathrm{BD})+10.249(\mathrm{LS})$
Tobin's $\mathrm{Q}=0.1228(\mathrm{BS})+1.0213(\mathrm{BC})+0.1809(\mathrm{BA})$

\section{Post-crisis period}

$\mathrm{ROA}=0.7694(\mathrm{BS})+13.327(\mathrm{BD})$

Tobin's $\mathrm{Q}=0.7935(\mathrm{BI})+0.2231(\mathrm{BC})-0.0608(\mathrm{BA})+1.9226(\mathrm{BD})$

\section{Corporate governance and financial performance nexus in the industrials industry}

In terms of Tobin's $Q$, the industrials companies were modestly affected, with a drop of $3.7 \%$ from 1.08 (pre-crisis) to 1.04 (post-crisis) (see Appendix 5). The accounting-based performance measure declined by $37 \%$ from 13.58 (pre-crisis)

TABLE 4: Regression results of the impact of corporate governance attributes on

\begin{tabular}{|c|c|c|c|}
\hline Panel & CG variables $^{\mathrm{a}}$ & Tobin's $Q^{b}$ & ROA $^{c}$ \\
\hline \multirow{11}{*}{$\begin{array}{l}\text { A: Pre-crisis } \\
\text { (2005-2007) }\end{array}$} & Perf (-1) & $(0.1840)^{* * *}$ & $(0.1141)^{* * *}$ \\
\hline & BS & $(0.1706)^{* * *}$ & $(0.6755)^{* * *}$ \\
\hline & $\mathrm{BI}$ & $\mathrm{N} / \mathrm{S}$ & $(-4.4861) * * *$ \\
\hline & $\mathrm{BC}$ & $(1.7962) * * *$ & $\mathrm{~N} / \mathrm{S}$ \\
\hline & BA & $(-0.2575)^{*}$ & $(0.4983)^{* * *}$ \\
\hline & $\mathrm{BD}$ & $(-9.8164) * * *$ & $(12.748)^{* * *}$ \\
\hline & LS & $\mathrm{N} / \mathrm{S}$ & $(-7.1772) * * *$ \\
\hline & Weighted stats: & & \\
\hline & Adjusted $R^{2}$ & 0.9853 & 0.9881 \\
\hline & Prob ( $F$-statistic) & 0.0000 & 0.0000 \\
\hline & Durbin Watson & 1.7935 & 1.9679 \\
\hline \multirow{12}{*}{$\begin{array}{l}\text { B: During } \\
\text { the crisis } \\
\text { (2008-2010) }\end{array}$} & CG variables & Tobin's $Q^{b}$ & ROA $^{c}$ \\
\hline & Perf $(-1)$ & $(0.0974)^{*}$ & $(0.6152)^{* * *}$ \\
\hline & BS & $(0.1228)^{* * *}$ & $N / S$ \\
\hline & $\mathrm{BI}$ & $\mathrm{N} / \mathrm{S}$ & $\mathrm{N} / \mathrm{S}$ \\
\hline & $\mathrm{BC}$ & $(1.0213)^{* * *}$ & $(-4.9820)^{*}$ \\
\hline & $\mathrm{BA}$ & $(0.1809)^{* *}$ & $\mathrm{~N} / \mathrm{S}$ \\
\hline & $\mathrm{BD}$ & $\mathrm{N} / \mathrm{S}$ & $(13.9987)^{*}$ \\
\hline & LS & $\mathrm{N} / \mathrm{S}$ & $(10.2493)^{* *}$ \\
\hline & Weighted stats: & & \\
\hline & Adjusted $R^{2}$ & 0.9944 & 0.9866 \\
\hline & $\operatorname{Prob}(F$-statistic) & 0.0000 & 0.0000 \\
\hline & Durbin Watson & 2.1217 & 2.5241 \\
\hline \multirow{12}{*}{$\begin{array}{l}\text { C: After the } \\
\text { crisis period } \\
\text { (2011-2013) }\end{array}$} & CG variables & Tobin's $Q^{b}$ & ROA $^{c}$ \\
\hline & Perf (-1) & $(0.6875)^{* * *}$ & $(0.6690)^{* * *}$ \\
\hline & BS & $\mathrm{N} / \mathrm{S}$ & $(0.7694)^{* *}$ \\
\hline & $\mathrm{BI}$ & $(0.7935)^{* * *}$ & $\mathrm{~N} / \mathrm{S}$ \\
\hline & $\mathrm{BC}$ & $(0.2231)^{* *}$ & $\mathrm{~N} / \mathrm{S}$ \\
\hline & BA & $(-0.0608)^{* *}$ & $\mathrm{~N} / \mathrm{S}$ \\
\hline & $\mathrm{BD}$ & $(1.9226)^{* * *}$ & $(13.327)^{* * *}$ \\
\hline & LS & $\mathrm{N} / \mathrm{S}$ & $\mathrm{N} / \mathrm{S}$ \\
\hline & Weighted stats: & & \\
\hline & Adjusted $R^{2}$ & 0.9924 & 0.9920 \\
\hline & $\operatorname{Prob}(F$-statistic) & 0.0000 & 0.0000 \\
\hline & Durbin Watson & 1.8852 & 2.3109 \\
\hline
\end{tabular}
Tobin's Q and Return on Asset for the consumer goods industry.

Note: Table 4 shows regression results of the impact of corporate governance attributes on Tobin's $Q$ and ROA for the consumer goods industry. Column 1 shows the corporate governance variables. Column 2 shows the impact of corporate governance on Tobin's $Q$, while Column 3 presents the impact of corporate governance on ROA. The abbreviations and definitions of the independent and control variables presented in this table are contained in Table 1. Panel A is for the pre-crisis period (2005-2007), Panel B is for the crisis period (20082010) and Panel $C$ is for the post-crisis period (2011-2013). Coefficients are in parentheses and the tabe excludes controlvariabs, which are reported in Appendix 2. $\mathrm{N} / \mathrm{S}$, no statistical significance; ROA, return on asset; $\mathrm{CG}$, corporate governance; Perf $(-1)$ performance lag; BS, board size; BI, board independence; BC, board committees; BA, board activity; BD, board diversity; LS, leadership structure.

***, significant at the 0.01 level; **, significant at the 0.05 level; *, significant at the 0.10 level. a, Column 1 shows the corporate governance variables; ${ }^{b}$, Column 2 shows the impact of corporate governance on Tobin's $Q ;{ }^{c}$, Column 3 presents the impact of corporate governance on ROA. 
to 8.58 (post-crisis). With regard to compliance levels in terms of King III, industrials companies improved their compliance levels, particularly during the crisis period. The average board size increased from 10.34 (pre-crisis) to 10.77 (during the crisis) and went down to 10.45 (post-crisis). In the same vein, the board met frequently (5.27 times) during the crisis period and reverted to meeting 4.9 times after the crisis. Companies within this industry also increased the proportion of non-white women representation from 13.8\% (pre-crisis) to $27 \%$ (during the crisis) and reduced the composition to 19.3\% (post-crisis).

Corporate governance variables, such as board independence, board committees, board diversity and leadership structure, all had a positive impact on Tobin's Q, pre-crisis period. During the crisis period, board size and board committees had a positive relationship with the performance measure, while after the crisis period, there was a positive nexus between Tobin's $\mathrm{Q}$ and both board size and board independence. Notably, during normal times, board independence appears to be associated positively with Tobin's $Q$, in support of the resource dependence theory. Interestingly, all corporate governance variables appear to have a positive impact on Tobin's $Q$ in varying periods, an indication that the market sees value in corporate governance structures for the industrials industry. The finding supports the study of Tshipa et al. (2018b) which posits that market returns favour agency and resource dependence theories.

While the size of the board was correlated positively to ROA during non-crisis periods, it had an inverse relationship during-crisis periods. In support of the stewardship theory, during the crisis period, board independence was correlated negatively with ROA, which indicates that the presence of independent non-executive directors is detrimental to the accounting returns.

All corporate governance variables except for board activity had a positive impact on ROA during varying periods. The board activity had an inverse relationship, which could mean that the frequency of board meetings had a negative impact on accounting returns. This may be because board members are paid for all the extraordinary meetings and more often than not management are removed from their workstations to attend these meetings. This could be opportunity costs for management, which may potentially lead to negative accounting returns.

Therefore, the corporate governance and performance model specific for the industrials industry is as follows (see Appendix 1):

\section{Pre-crisis period}

$\mathrm{ROA}=0.1431(\mathrm{BS})-1.5514(\mathrm{BC})+1.5559(\mathrm{LS})$

Tobin's $\mathrm{Q}=-0.0096(\mathrm{BS})+0.1867(\mathrm{BI})+0.0277(\mathrm{BC})$

$$
+0.1652(\mathrm{BD})+0.2652(\mathrm{LS})
$$

During-crisis period

$\mathrm{ROA}=-0.1097(\mathrm{BS})-4.4120(\mathrm{BI})+2.1420(\mathrm{BC})-0.4913(\mathrm{BA})$

$$
+1.8578(\mathrm{BD})-1.3179(\mathrm{LS})
$$

Tobin's $\mathrm{Q}=0.0067(\mathrm{BS})+0.1368(\mathrm{BC})$

\section{Post-crisis period}

$$
\begin{aligned}
\mathrm{ROA} & =0.2012(\mathrm{BS})+4.8484(\mathrm{BI})-1.7845(\mathrm{BC}) \\
& -0.3986(\mathrm{BA})
\end{aligned}
$$

Tobin's $\mathrm{Q}=0.0049(\mathrm{BS})+0.5680(\mathrm{BI})-0.1466(\mathrm{BC})$

\begin{tabular}{|c|c|c|c|}
\hline Panel & CG variables $^{a}$ & Tobin's $Q^{b}$ & ROA $^{c}$ \\
\hline \multirow{11}{*}{$\begin{array}{l}\text { A: Pre-crisis } \\
\text { (2005-2007) }\end{array}$} & Perf (-1) & $(0.6740)^{* * *}$ & $(0.3766)^{* * *}$ \\
\hline & BS & $(-0.0096)^{* * *}$ & $(0.1431)^{* * *}$ \\
\hline & $\mathrm{BI}$ & $(0.1867)^{* * *}$ & $N / S$ \\
\hline & $B C$ & $(0.0277)^{* *}$ & $(-1.5514)^{* *}$ \\
\hline & BA & $\mathrm{N} / \mathrm{S}$ & $N / S$ \\
\hline & $\mathrm{BD}$ & $(0.1652)^{* *}$ & $\mathrm{~N} / \mathrm{S}$ \\
\hline & LS & $(0.2652)^{* * *}$ & $(1.5559) * * *$ \\
\hline & Weighted stats: & & \\
\hline & Adjusted $R^{2}$ & 0.9570 & 0.9461 \\
\hline & Prob (F-statistic) & 0.0000 & 0.0000 \\
\hline & Durbin Watson & 1.4173 & 1.7796 \\
\hline \multirow{12}{*}{$\begin{array}{l}\text { B: During } \\
\text { the crisis } \\
\text { (2008-2010) }\end{array}$} & CG variables & Tobin's $Q^{b}$ & $R^{\prime} A^{c}$ \\
\hline & Perf $(-1)$ & $(0.7827)^{* * *}$ & $(0.7967)^{* * *}$ \\
\hline & BS & $(0.0067)^{*}$ & $(-0.1097)^{* * *}$ \\
\hline & $\mathrm{BI}$ & $\mathrm{N} / \mathrm{S}$ & $(-4.4120)^{* * *}$ \\
\hline & $\mathrm{BC}$ & $(1.1368)^{* * *}$ & $(2.1420)^{* * *}$ \\
\hline & BA & $\mathrm{N} / \mathrm{S}$ & $(-0.4913)^{* * *}$ \\
\hline & $\mathrm{BD}$ & $\mathrm{N} / \mathrm{S}$ & $(1.8578)^{* * *}$ \\
\hline & LS & $N / S$ & $(-1.3179)^{* *}$ \\
\hline & Weighted stats & & \\
\hline & Adjusted $R^{2}$ & 0.9001 & 0.9954 \\
\hline & Prob (F-statistic) & 0.0000 & 0.0000 \\
\hline & Durbin Watson & 2.3031 & 1.9089 \\
\hline \multirow{12}{*}{$\begin{array}{l}\text { C: After the } \\
\text { crisis period } \\
\text { (2011-2013) }\end{array}$} & CG variables & Tobin's $Q^{b}$ & $R^{\prime} A^{c}$ \\
\hline & Perf (-1) & $(0.8881)^{* * *}$ & $(0.7107)^{* * *}$ \\
\hline & BS & $(0.0049)^{* * *}$ & $(0.2012)^{* * *}$ \\
\hline & $\mathrm{BI}$ & $(0.5680)^{* * *}$ & $(4.8484)^{* * *}$ \\
\hline & $\mathrm{BC}$ & $(-0.1466) * * *$ & $(-1.7845)^{* * *}$ \\
\hline & BA & $\mathrm{N} / \mathrm{S}$ & $(-0.3986)^{* * *}$ \\
\hline & $\mathrm{BD}$ & $(-0.2498)^{* *}$ & $N / S$ \\
\hline & LS & $\mathrm{N} / \mathrm{S}$ & $\mathrm{N} / \mathrm{S}$ \\
\hline & Weighted stats: & & \\
\hline & Adjusted $R^{2}$ & 0.9885 & 0.9739 \\
\hline & $\operatorname{Prob}$ (F-statistic) & 0.0000 & 0.0000 \\
\hline & Durbin Watson & 1.6186 & 1.6680 \\
\hline
\end{tabular}

$$
-0.2498(\mathrm{BD})
$$

TABLE 5: Regression results of the impact of corporate governance attributes on Tobin's Q and Return on Asset for the industrials industry.

Note: Table 5 shows regression results of the impact of corporate governance attributes on Tobin's $Q$ and ROA for the industrials industry. Column 1 shows the corporate governance variables. Column 2 shows the impact of corporate governance on Tobin's $Q$, while Column 3 presents the impact of corporate governance on ROA. The abbreviations and definitions of the independent and control variables presented in this table are contained in Table 1. Panel A is for the pre-crisis period (2005-2007), Panel B is for the crisis period (2008-2010) and Panel C is for the post-crisis period (2011-2013). Coefficients are in parentheses and the table excludes control variables, which are reported in Appendix 2

$\mathrm{N} / \mathrm{S}$, no statistical significance; ROA, return on asset; CG, corporate governance; Perf (-1), performance lag; BS, board size; BI, board independence; BC, board committees; BA, board activity; BD, board diversity; LS, leadership structure.

***, significant at the 0.01 level; **, significant at the 0.05 level; *, significant at the 0.10 level.

a, Column 1 shows the corporate governance variables; ${ }^{b}$, Column 2 shows the impact of corporate governance on Tobin's $Q ;{ }^{c}$, Column 3 presents the impact of corporate governance
on ROA. 


\section{Corporate governance and financial performance nexus in the basic materials industry}

Appendix 6 presents the descriptive statistics for the basic materials industry. The basic materials industry was the most severely hit by the global financial crisis, with Tobin's Q plummeting by $87 \%$ from 8.76 before the crisis to 1.11 after the crisis. Similarly, ROA plunged by $80 \%$ from 14.47 pre-crisis to 2.87 post-crisis. The descriptive variables also demonstrate that all corporate governance characteristics improved during the three economic periods. In particular, the average leadership structure was $100 \%$ during the crisis, indicating that companies within this industry completely complied with the King III recommendation of separating the roles of CEO and chairman.

The size of the board had a positive impact on Tobin's Q, before the crisis and after the crisis, indicating that board size only influenced company performance during noncrisis times. During crisis times, board committees and board activity had an inverse influence on the marketbased performance measures, while board independence had a positive impact, supporting the resource dependence theory, namely that independent non-executive directors are resourceful and assist in reducing the agency costs. Therefore, of the six corporate governance attributes, only board size, board independence and board committees had a positive impact on the market returns at specific economic periods. This indicates that for the basic materials industry, diversifying the board in terms of race and gender, separating the roles of chairman and CEO, as well as convening at least four times a year, did not generate market returns.

Regarding the accounting-based measure, board size had a negative influence on ROA during the pre-crisis period and during the crisis period, with the direction of influence changing after the crisis period. Consistent with the resource dependence theory, board independence had a positive impact on company performance during the crisis period. One reason for this result could be that in a recession, independent outside directors, due to interlocking and their web of network, could be providers of timely information and resources which are beneficial to the performance of a company.

In support of the agency theory, board activity had a positive relationship during the entire period and pre-crisis period, while board diversity had a positive association in all intervening periods, which is an indication that diversifying boards in this industry is critical regardless of the period. However, separating the roles of chairman and CEO as well as establishing nomination, remuneration and audit/risk committees did not exhibit positive accounting returns for the basic materials industry. Therefore, the corporate governance and performance model specific for the basic materials industry is as follows (see Appendix 1):
Pre-crisis period

$\mathrm{ROA}=-1.0329(\mathrm{BS})+0.5359(\mathrm{BA})+6.9678(\mathrm{BD})-13.107(\mathrm{LS})$

Tobin's Q $=0.3898(\mathrm{BS})$

During-crisis period

$\mathrm{ROA}=-3.5881(\mathrm{BS})+19.029(\mathrm{BI})+13.899(\mathrm{BD})$

Tobin's $\mathrm{Q}=0.3420(\mathrm{BI})-0.2505(\mathrm{BC})-0.0283(\mathrm{BA})$

Post-crisis period

$\mathrm{ROA}=0.5673(\mathrm{BS})-6.8687(\mathrm{BI})-6.8954(\mathrm{BC})+10.539(\mathrm{BD})$

Tobin's $\mathrm{Q}=0.0327(\mathrm{BS})+0.1039(\mathrm{BI})-0.5823(\mathrm{BD})$

TABLE 6: Regression results of the impact of corporate governance attributes on Tobin's $Q$ and Return on Asset for the basic material industry.

\begin{tabular}{|c|c|c|c|}
\hline Panel & CG variables $^{\mathrm{a}}$ & Tobin's $Q^{b}$ & $\mathrm{ROA}^{\mathrm{c}}$ \\
\hline \multirow{11}{*}{$\begin{array}{l}\text { A: Pre-crisis } \\
(2005-2007)\end{array}$} & Perf $(-1)$ & $(0.4799) * * *$ & $(0.1402) * * *$ \\
\hline & BS & $(0.3898)^{* * *}$ & $(-1.0329)^{* * *}$ \\
\hline & $\mathrm{BI}$ & $\mathrm{N} / \mathrm{S}$ & $\mathrm{N} / \mathrm{S}$ \\
\hline & $\mathrm{BC}$ & $\mathrm{N} / \mathrm{S}$ & $N / S$ \\
\hline & $\mathrm{BA}$ & $\mathrm{N} / \mathrm{S}$ & $(0.5359) * * *$ \\
\hline & $\mathrm{BD}$ & $\mathrm{N} / \mathrm{S}$ & $(6.9678)^{* * *}$ \\
\hline & LS & $\mathrm{N} / \mathrm{S}$ & $(-13.1072)^{* * *}$ \\
\hline & Weighted stats: & & \\
\hline & Adjusted $R^{2}$ & 0.5518 & 0.9771 \\
\hline & Prob ( $F$-statistic) & 0.0000 & 0.0000 \\
\hline & Durbin Watson & 1.2224 & 1.5115 \\
\hline \multirow{12}{*}{$\begin{array}{l}\text { B: During } \\
\text { the crisis } \\
\text { (2008-2010) }\end{array}$} & CG variables & Tobin's $Q^{b}$ & $\mathrm{ROA}^{\mathrm{c}}$ \\
\hline & Perf (-1) & $(0.7869)^{* * * *}$ & $(0.2431) * * *$ \\
\hline & BS & $\mathrm{N} / \mathrm{S}$ & $(-3.5881) * * *$ \\
\hline & $\mathrm{BI}$ & $(0.3420)^{* *}$ & $(19.0297)^{* * *}$ \\
\hline & $\mathrm{BC}$ & $(-0.2505)^{* * *}$ & $N / S$ \\
\hline & BA & $(-0.0283)^{* * *}$ & $N / S$ \\
\hline & $\mathrm{BD}$ & $\mathrm{N} / \mathrm{S}$ & $(13.8992)^{* * *}$ \\
\hline & LS & $\mathrm{N} / \mathrm{S}$ & $\mathrm{N} / \mathrm{S}$ \\
\hline & Weighted stats: & & \\
\hline & Adjusted $R^{2}$ & 0.9995 & 0.9719 \\
\hline & Prob ( $F$-statistic) & 0.0000 & 0.0000 \\
\hline & Durbin Watson & 2.7165 & 1.7503 \\
\hline \multirow{12}{*}{$\begin{array}{l}\text { C: After the } \\
\text { crisis period } \\
\text { (2011-2013) }\end{array}$} & CG variables & Tobin's $Q^{b}$ & $\mathrm{ROA}^{\mathrm{c}}$ \\
\hline & Perf $(-1)$ & $(1.1666)^{* * *}$ & $(0.4604) * * *$ \\
\hline & BS & $(0.0327)^{* * * *}$ & $(0.5673) * * *$ \\
\hline & $\mathrm{BI}$ & $(0.1039)^{* *}$ & $(-6.8687)^{* * *}$ \\
\hline & $\mathrm{BC}$ & $N / S$ & $(-6.8954) * * *$ \\
\hline & BA & $\mathrm{N} / \mathrm{S}$ & $\mathrm{N} / \mathrm{S}$ \\
\hline & $\mathrm{BD}$ & $(-0.5823)^{* * *}$ & $(10.5390)^{* * *}$ \\
\hline & LS & $\mathrm{N} / \mathrm{S}$ & $N / S$ \\
\hline & Weighted stats: & & \\
\hline & Adjusted $R^{2}$ & 0.9947 & 0.9536 \\
\hline & Prob ( $F$-statistic) & 0.0000 & 0.0000 \\
\hline & Durbin Watson & 2.0193 & 2.1234 \\
\hline
\end{tabular}

Note: Table 6 shows regression results of the impact of corporate governance attributes on Tobin's $Q$ and ROA for the basic material industry. The abbreviations and definitions of the independent and control variables presented in this table are contained in Table 1. Panel A is for the pre-crisis period (2005-2007), Panel B is for the crisis period (2008-2010) and Panel $\mathrm{C}$ is for the post-crisis period (2011-2013). Coefficients are in parentheses and the table excludes control variables, which are reported in Appendix 2 .

$\mathrm{N} / \mathrm{S}$, no statistical significance; ROA, return on asset; CG, corporate governance; Perf $(-1)$, performance lag; BS, board size; BI, board independence; BC, board committees; BA, board activity; BD, board diversity; $L S$, leadership structure.

*, significant at the 0.10 level; **, significant at the 0.05 level; ***, significant at the 0.01 level. a, Column 1 shows the corporate governance variables; ${ }^{b}$, Column 2 shows the impact of corporate governance on Tobin's $Q ;{ }^{c}$, Column 3 presents the impact of corporate governance on ROA. 


\section{Conclusions}

The objective of this study was to investigate empirically the existence of industry nuances in the relationship between corporate governance and financial performance of companies listed in the Johannesburg Stock Exchange.

Findings of this study concluded that the relationship between corporate governance and company performance differed from industry to industry as well as from period to period and should not be replicated. For instance, in line with the stewardship theory and during the pre-crisis period, board independence had an inverse relationship to performance for the financials industry, which could imply that due to the nature and complexity of the financials industry, independent non-executives added no value as they did not understand the business better than executive management. These findings are important given the increasing trend towards boardroom independence around the globe. In this case, and contrary to King III, it would make sense to have more executive management members than independent board members. In the same vein, board independence had no impact whatsoever on the basic materials industry.

The study is novel because it is the first to explore the relationship of corporate governance to company performance using a dynamic modelling approach for the South African market during three economic periods having taken industry nuances into account. The findings of the study significantly contribute towards a better understanding of international diversity in corporate governance by providing empirical evidence from the African emerging markets. The study also extends the corporate governance literature by enriching the understanding of the interaction between industry and economics dynamics and corporate governance and performance nexus.

Consequently, the findings of the study have the following implications:

\section{Policy implications}

The implications of the study findings are manifold. First, all South African companies listed on the JSE are legally required to report on the application of the King III on corporate governance, as required by Section 8.63 of the JSE Listings Requirements. To this end, several implications can be drawn from the level of compliance by South African listed companies to the King III and JSE Listings Requirements. The analyses of the levels of corporate governance compliance indicated that corporate governance standards generally improved over the period of examination, specifically during the crisis period. Incidentally, the crisis period coincided with the implementation of King III in South Africa. This implies that concerted effort of improving corporate governance in South Africa by the various stakeholders, notably the Institute of Directors of South Africa, Financial Services Board and the JSE, among others, has yielded some benefits. However, this study cautions the move from 'apply or explain' by King III to 'apply and explain', as advocated by the recently published King IV (Institute of Directors of South Africa 2016), because the study showed that compliance levels and performance differed on the basis of the timing and the industry classification. For instance, during the crisis periods, board independence was vital for the basic materials industry and unfavourable for the consumer services industry. Hence it would be detrimental to prescribe to the consumer services industry to have more independent non-executive directors in their boardroom. Finally, the results also indicated that South African companies with a greater number of board members exhibited higher accounting and market returns during non-crisis periods. However, the study found that the maximum board size should be 14 board members with the minimum being four, depending on the economic period and industry type. Therefore, regulators should give companies latitude in terms of the size of the board.

\section{Limitations}

Despite the findings, this study, like any other study, had limitations. First, the results were based on South African listed companies covering only the five major industries. While focusing on South Africa is beneficial in giving more detailed results on the relationship between corporate governance and company performance, these results may not be generalisable as they are specific only to South Africa and to the five industries. Consequently, future studies should focus on other African countries in order to provide global comparability of the corporate governance literature.

Few studies that look at the impact of corporate governance and performance during crisis and non-crisis consider only the financial sector. To enrich the empirical literature and allow for comparison, similar studies to this study should be replicated on a global scale.

Arguably, excluding other companies introduces survivorship bias. However, the sample selection criteria generated comparatively larger firm-year observations in relation to those of prior South African studies to the extent that the generalisation of the research results may not be substantially impaired. Notwithstanding, these weaknesses could potentially limit the generalisation of the research findings.

Therefore, the research findings must be interpreted in the light of the above limitations. Also, these limitations potentially represent avenues for future research. The next section points out potential avenues for future research and improvements.

\section{Avenues for further studies}

Based on the results of this study, some future research work is recommended. First, this study examined the 
effect of corporate governance on company performance from the perspective of agency, resource dependence and stewardship theories. This study could be enhanced by investigating the relationship between corporate governance and company performance using other established corporate governance theories such as human capital, signalling and institutional theories.

The media play an important role in corporate governance promotion (Lauterbach \& Pajuste 2017) and market returns are sensitive to public opinion. Future research could consider how the media also play a monitoring role to curb agency costs.

Most corporate governance studies produce inconclusive results. To obviate this, future studies could employ other methodologies such as triangulation. Mixing hermeneutic and quantitative methods could mitigate methodological artifacts and assist in establishing a clear link between corporate governance and company performance (Rebeiz 2015).

\section{Acknowledgements Competing interests}

The authors declare that they have no financial or personal relationships that may have inappropriately influenced them in writing this article.

\section{Authors' contributions}

J.T. conducted this study in pursuit of his doctoral degree. L.M.B., H.W. and E.dT. were his supervisors. All authors contributed to the writing of this article.

\section{References}

Abels, P.B. \& Martelli, J.T., 2013, 'CEO duality: How many hats are too many?', Corporate Governance: The International Journal of Business Society 13(2), 135147. https://doi.org/10.1108/14720701311316625

Adegbite, E., Amaeshi, K. \& Amao, O., 2012, 'The politics of shareholder activism in Nigeria', Journal of Business Ethics 105(3), 389-402. https://doi.org/10.1007/ s10551-011-0974-y

Aduda, J., Chogii, R. \& Magutu, P.O., 2013, 'An empirical test of competing corporate governance theories on the performance of companies listed at the Nairobi securities exchange', European Scientific Journal 9(13), 107-137.

Afrifa, G.A. \& Tauringana, V., 2015, 'Corporate governance and performance of UK listed small and medium enterprises', Corporate Governance 15(5), 719-733. https://doi.org/10.1108/CG-03-2015-0029

Aguilera, R.V. \& Cuervo-Cazurra, A., 2009, 'Codes of good governance', Corporate Governance: An International Review 17(3), 376-387. https://doi.org/10.1111/j. 1467-8683.2009.00737.x

Ammann, M., Oesch, D. \& Schmid, M.M., 2013, 'Product market competition, corporate governance and firm value: Evidence from the EU area', European Financial Management 19(3), 452-469. https://doi.org/10.1111/j.1468-036X. 2010.00605.x

Arora, A. \& Sharma, C., 2016, 'Corporate governance and firm performance in developing countries: Evidence from India', Corporate Governance 16(2), 420436. https://doi.org/10.1108/CG-01-2016-0018

Arosa, B., Iturralde, T. \& Maseda, A., 2013, 'The board structure and firm performance in SMEs: Evidence from Spain', Investigaciones Europeas de Dirección Economía de la Empresa 19, 127-135. https://doi.org/10.1016/j.iedee.2012.12.003

Aslam, M. \& Pasha, G.R., 2007, 'Adaptive estimation of heteroscedastic money demand model of Pakistan', Pakistan Journal of Statistics and Operation Research 3(2), 109-115. https://doi.org/10.18187/pjsor.v3i2.65

Ayadi, O.F., Ojo, A.T., Ayadi, M.F. \& Adetula, D.T., 2015, 'Gender diversity in the governance of the Nigerian securities market', Corporate Governance 15(5), 734-746. https://doi.org/10.1108/CG-01-2015-0007
Baranchuk, N. \& Dybvig, P.H., 2009, 'Consensus in diverse corporate boards', Review of Financial Studies 22(2), 715-747. https://doi.org/10.1093/rfs/hhn052

Bonazzi, L. \& Islam, S.M., 2007, 'Agency theory and corporate governance: A study of the effectiveness of board in their monitoring of the CEO', Journal of Modelling in Management 2(1), 7-23. https://doi.org/10.1108/17465660710733022

Brown, P., Beekes, W. \& Verhoeven, P., 2011, 'Corporate governance, accounting and finance: A review', Accounting \& Finance 51(1), 96-172. https://doi.org/10.1111/ j.1467-629X.2010.00385.x

Bruno, V. \& Claessens, S., 2010, 'Corporate governance and regulations: Can there be too much of a good thing?', Journal of Financial Intermediation 19(4), 461-482. https://doi.org/10.1016/j.jfi.2009.10.001

Bussin, M. \& Modau, M.F., 2015, 'The relationship between chief executive officer remuneration and financial performance in South Africa between 2006 and 2012', South African Journal of Human Resource Management 13(1), 1-18.

Carter, D.A., Simkins, B.J. \& Simpson, W.G., 2003, 'Corporate governance, board diversity and firm value', Financial Review 38(1), 33-53. https://doi.org/ 10.1111/1540-6288.00034

Chatterjee, S. \& Hadi, A.S., 2012, Regression analysis by example, John Wiley \& Sons, Hoboken, NJ.

Clarke, T., 1998, 'Research on corporate governance', Corporate Governance: An International Review 6(1), 57-66. https://doi.org/10.1111/1467-8683.00081

Cohen, J.R., Krishnamoorthy, G. \& Wright, A.M., 2008, 'Form versus substance: The implications for auditing practice and research of alternative perspectives on corporate governance', Auditing: A Journal of Practice and Theory 27(2), 181-198. https://doi.org/10.2308/aud.2008.27.2.181

Dalton, D.R., Daily, C.M., Johnson, J.L. \& Ellstrand, A.E., 1999, 'Number of directors and financial performance: A meta-analysis', The Academy of Management Journal42(6), 674-686. https://doi.org/10.2307/256988

Davis, J.H., Schoorman, F.D. \& Donaldson, L., 1997, 'Davis, Schoorman and Donaldson reply: The distinctiveness of agency theory and stewardship theory', The Academy of Management Review 22(3), 611-613.

Diebold, F.X., 2016, Time series econometrics, viewed 21 October 2015, from http:// www.ssc.upenn.edu/ fdiebold/Textbooks.html/

Donaldson, L., 1990, 'The Ethereal hand: Organisational economics and management theory', Academy of Management Review 15(3), 369-381. https://doi. org/10.1177/031289629101600103

Donaldson, L. \& Davis, J.H., 1991, 'Stewardship theory or agency theory: CEO governance and shareholder returns', Australian Journal of Management16(1), 49-64.

Durisin, B. \& Puzone, F., 2009, 'Maturation of corporate governance research, 19932007: An assessment', Corporate Governance: An international Review 17(3), 266-291. https://doi.org/10.1111/j.1467-8683.2009.00739.x

Erkens, D., Hung, M. \& Matos, P., 2012, 'Corporate governance in the 2007-2008 financial crisis: Evidence from financial institutions worldwide', Journal of Corporate Finance 18(2), 389-411. https://doi.org/10.1016/j.jcorpfin.2012.01.005

Fauzi, F. \& Locke, S., 2012, 'Board structure, ownership structure and firm performance: A study of New Zealand listed firms', Asian Academy of Management Journal of Accounting \& Finance 8(2), 43-67.

Filatotchev, I. \& Boyd, B.K., 2009, 'Taking stock of corporate governance research while looking to the future', Corporate Governance: An International Review 17(3), 257-265. https://doi.org/10.1111/j.1467-8683.2009.00748.x

Gartenberg, C. \& Pierce, L., 2017, 'Subprime governance: Agency costs in vertically integrated banks and the 2008 mortgage crisis', Strategic Management Journal 38(2), 300-321. https://doi.org/10.1002/smj.2481

Greene, W.H., 2002, Econometric analysis, 5th edn., Prentice-Hall, Upper Saddle River, NJ. Gujarati, D.N., 2004, Basic econometrics, 4th edn., McGraw-Hill, New York.

Guest, P.M., 2009, 'The impact of board size on firm performance: Evidence from the UK', The European Journal of Finance 15(4), 385-404. https://doi.org/10.1080/ 13518470802466121

Habib, M.A., 2016, 'Relationship between corporate governance and firm performance: A case study in Bangladesh', International Scholar Journal of Accounting and Finance 2(1), 11-20.

Hafsi, T. \& Turgut, G., 2013, 'Boardroom diversity and its effect on social performance: Conceptualization and empirical evidence', Journal of Business Ethics 112(3), 463479. https://doi.org/10.1007/s10551-012-1272-z

Haniffa, R. \& Hudaib, M., 2006, 'Corporate governance structure and performance of Malaysian listed companies', Journal of Business Finance and Accounting 33(7-8), 1034-1062. https://doi.org/10.1111/j.1468-5957.2006.00594.x

Haniffa, R.M. \& Cooke, T.E., 2002, 'Culture, corporate governance and disclosure in Malaysian corporations', Abacus 38(3), 317-349. https://doi.org/10.1111/14676281.00112

Hillman, A.J. \& Dalziel, T., 2003, 'Boards of directors and firm performance: Integrating agency and resource dependence perspectives', Academy of Management Review 28(3), 383-396.

Hung, H., 1998, 'A typology of the theories of the roles of governing boards', Corporate Governance 6(2), 101-111. https://doi.org/10.1111/1467-8683.00089

INET BFA, 2016, Research domain. Software and database. Johannesburg, South Africa.

Institute of Directors in Southern Africa, 2002, 'King Report on Corporate Governance for South Africa 2002', IoDSA, Johannesburg, South Africa.

Institute of Directors in Southern Africa, 2009, 'King Report on Governance for South Africa 2009', loDSA, Johannesburg, South Africa. 
Institute of Directors in Southern Africa, 2016, 'King IV Report on Corporate Governance for South Africa, 2016', IoDSA, Johannesburg, South Africa.

Jensen, M. \& Meckling, W., 1976, 'Theory of the firm: Managerial behaviour, agency cost and ownership structure', Journal of Financial Economics 3(4), 305-360. https://doi.org/10.1016/0304-405X(76)90026-X

Johnson, S., Boone, P., Breach, A. \& Friedman, E., 2000, 'Corporate governance in the Asian financial crisis', Journal of Financial Economics 58(1/2), 141-186. https:// doi.org/10.1016/S0304-405X(00)00069-6

Kakabadse, A. \& Korac-Kakabadse, N., 2002, 'Corporate governance in South Africa: Evaluating the King 2 Report', Journal of Change Management 2(4), 305-317. https://doi.org/10.1080/714042518

Kirkpatrick, G., 2009, 'Corporate governance lessons from the financial crisis', Financial Market Trends 3(1), 1-30. https://doi.org/10.1787/fmt-v2009-art3-en

Kumar, N. \& Singh, J.P., 2013, 'Global financial crisis: Corporate governance failures and lessons', Journal of Finance, Accounting and Management 4(1), 21-34.

Larcker, D.F. and Rusticus, T.O., 2010, 'On the use of instrumental variables in accounting research', Journal of Accounting and Economics 49(3), 186-205.

Lauterbach, B. and Pajuste, A. 2017, 'The media and firm reputation roles in corporate governance improvements: Lessons from European dual class share unifications', Corporate Governance: An International Review, 25(1), 4-19.

Mangena, M. \& Chamisa, E., 2008, 'Corporate governance and incidences of listings suspension by the JSE securities exchange of South Africa: An empirical analysis', The International Journal of Accounting 43(1), 28-44. https://doi.org/10.1016/j. intacc.2008.01.002

Mina, A., Lahr, H. \& Hughes, A., 2013, 'The demand and supply of external finance for innovative firms', Industrial and Corporate Change 22(4), 1-33. https://doi. org/10.1093/icc/dtt020

Moscu, R.G., 2013, 'Does CEO duality really affect corporate performance?' International Journal of Academic Research in Economics and Management Sciences 2(1), 156-166.

Mohammed, A., Che-Ahmad, A. \& Aljaaidi, K.S., 2012, 'Factors associated with firm performance: Empirical evidence from the kingdom of Saudi Arabia', Accounting \& Taxation 4(2), 49-56.

Muchemwa, M.R., Padia, N. \& Callaghan, C.W., 2016, 'Board composition, board size and financial performance of Johannesburg Stock Exchange companies', SAJEMS 19(4), 497-513. https://doi.org/10.4102/sajems.v19i4.1342

Muth, M. \& Donaldson, L., 1998, 'Stewardship theory and board structure: A contingency approach', Corporate Governance: An International Review 6(1) 5-28. https://doi.org/10.1111/1467-8683.00076

Nelson, T., Singh, K., Elenkov, D., Ma, R., Krug, J. \& Davis, B., 2013, 'Theoretical contributions to governance of smaller firms', Journal of Business and Entrepreneurship 25(1), 21-41.

Nguyen, T., Locke, S. \& Reddy, K., 2014, 'A dynamic estimation of governance structures and financial performance for Singaporean companies', Economic Modelling 40(C), 1-11. https://doi.org/10.1016/j.econmod.2014.03.013

Nguyen, T., Locke, S. \& Reddy, K., 2015, 'Does boardroom gender diversity matter? Evidence from a transitional economy', International Review of Economics and Finance 40(C), 184-202. https://doi.org/10.1016/j.iref.2014.11.022

Nicholson, G.J. \& Kiel, G.C., 2007, 'Can directors impact performance? A case-based test of three theories of corporate governance', Corporate Governance: An International Review 15(4), 585-608. https://doi.org/10.1111/j.1467-8683. 2007.00590.x

Ntim, C.G., Opong, K.K., Danbolt, J. \& Thomas, D.A., 2012, 'Voluntary corporate governance disclosures by post-apartheid South African corporations', Journal of Applied Accounting Research 13(2), 122-144. https://doi.org/10.1108/0967542 1211254830

Olsson, U.H., Foss, T., Troye, S.V. \& Howell, R.D., 2000, 'The performance of ML, GLS and WLS estimation in structural equation modeling under conditions of misspecification and non-normality', Structural Equation Modeling 7(4), 557-595. https://doi.org/10.1207/S15328007SEM0704_3

Orazalin, N., Mahmood, M. \& Lee, K.J., 2016, 'Corporate governance, financial crises and bank performance: Lessons from top Russian banks', Corporate Governance 16(5), 798-814. https://doi.org/10.1108/CG-10-2015-0145

Pamburai, H.H., Chamisa, E., Abdulla, C. \& Smith, C., 2015, 'An analysis of corporate governance and company performance: A South African perspective', South African Journal of Accounting Research 29(2), 115-131. https://doi.org/10.1080/ African Journal of Accountin

Pfeffer, J., 1972, 'Size and composition of corporate boards of directors: The organization and its environment', Administrative Science Quarterly 17(2), 218-228. https://doi.org/10.2307/2393956

Rad, S.A., 2014, 'The relationship between corporate governance practices and cost of capital in large listed companies of New Zealand and Singapore', Unpublished doctoral thesis, University of Waikito, New Zealand.
Rebeiz, K.S., 2015, 'Boardroom's independence and corporate performance: The everelusive conundrum', Corporate Governance 15(5), 747-758. https://doi.org/ 10.1108/CG-07-2015-0096

Republic of South Africa, 2008, 'The Companies Act, 71 of 2008', Government Printers, Pretoria, South Africa.

Roberts, M.R. \& Whited, T.M., 2013, 'Endogeneity in empirical corporate finance', in M.H. Goerge M. Constantinides \& M.S. Rene (eds.), Handbook of the economics of finance, vol. 2 Part A, pp. 493-572, Elsevier, Saint Louis, MO.

Rodriguez-Fernandez, M., Fernandez-Alonso, S. \& Rodriguez-Rodriguez, J., 2014 'Board characteristics and firm performance in Spain', Corporate Governance 14(4), 485-503. https://doi.org/10.1108/CG-01-2013-0013

Schultz, E.L., Tan, D.T. \& Walsh, K.D., 2010, 'Endogeneity and the corporate governance-performance relation', Australian Journal of Management 35(2), 145-163. https://doi.org/10.1177/0312896210370079

Schwarz, C. J. 2015, 'Detecting trends over time. In course notes for beginning and intermediate statistics', viewed 06 June 2014, from http://www.stat.sfu. $\mathrm{ca} / \sim \mathrm{cschwarz} /$ CourseNotes

Sheikh, N.A. \& Wang, Z., 2012, 'Effects of corporate governance on capital structure: Empirical evidence from Pakistan', Corporate Governance 12(5), 629-641. https:// doi.org/10.1108/14720701211275569

Shropshire, C., 2010, 'The role of interlocking director and board receptivity in the diffusion of practices?', Academy of Management Review 35(2), 355-372. https:// doi.org/10.5465/AMR.2010.48463333

Spira, L.F. \& Bender, R., 2004, 'Compare and contrast: Perspective on board committees', Corporate Governance: An International Review 12(4), 489-499. https://doi.org/10.1111/j.1467-8683.2004.00389.x

Sternberg, E., 1998, Corporate governance: Accountability in the market viewed 17 October 2015, from https://iea.org.uk/wp-content/uploads/2016/07/ upldbook227pdf/

Taljaard, C.C.H., Ward, M.J.D. \& Muller, C.J., 2015, 'Board diversity and financial performance: A graphical time-series approach', SAJEMS 18(3), 425-448. https:// doi.org/10.4102/sajems.v18i3.926

Tshipa, J., Brummer, L.M., Wolmarans, H. \& Du Toit, E, 2018a, 'The impact of flexible corporate governance disclosures on value relevance. Empirical evidence from South Africa', Corporate Governance: The International Journal of Business in Society. https://doi.org/10.1108/CG-05-2017-0106

Tshipa, J., Brummer, L.M., Wolmarans, H. \& Du Toit, E., 2018b, 'Corporate governance and financial performance in the midst of exogenous shocks: A study of companies listed on the Johannesburg Stock Exchange', Management Dynamics 27(1), 20-38.

Tshipa, J. \& Mokoaleli-Mokoteli, T., 2015, 'The South African code of corporate governance: The relationship between compliance and financial performance: Evidence from South African publicly listed companies', Corporate Ownership and Control 12(2), 149-169. https://doi.org/10.22495/cocv12i2p12

Van der Walt, N. \& Ingley, C., 2003, 'Board dynamics and the influence of professional background, gender and ethnic diversity of directors', Corporate Governance: An International Review 11(3), 218-234. Corporate Governance: An International Review 11(3), 218-234.https://doi.org/10.1111/1467-8683.00320

Van Essen, M., Engelen, P.J. \& Carney, M., 2013, 'Does "good" corporate governance help in a crisis? The impact of country and firm level governance mechanisms in the European Financial Crisis', Corporate Governance: An International Review 21(3), 201-224. https://doi.org/10.1111/corg.12010

Vinten, G., 2002, 'The corporate governance lessons of Enron', Corporate Governance 2(4), 4-9. https://doi.org/10.1108/14720700210447632

Vintilă, G. \& Gherghina, S.C., 2013, 'Board of directors' independence and firm value: Empirical evidence based on the Bucharest Stock Exchange listed companies', International Journal of Economics and Financial Issues 3(4), 885-900.

Wagana, D.M., 2016, 'Corporate governance, board gender diversity and corporate performance: A critical review of literature', European Scientific Journal 12(7), 221-233.

Wahba, H. 2015, 'The joint effect of board characteristics on financial performance: Empirical evidence from Egypt', Review of Accounting and Finance 14(1), 1-37.

Waweru, V.M., 2014, 'Determinants of quality corporate governance in sub-Saharan Africa: Evidence from Kenya and South Africa', Managerial Auditing Journal 29(5), 455-485. https://doi.org/10.1108/MAJ-07-2013-0897

Whittred, G., 1993, 'Donaldson and Davis on CEO governance and shareholder returns: A comment', Australian Journal of Management 18(1), 103-107. https:// doi.org/10.1177/031289629301800106

Wintoki, M.B., Linck, J.S. \& Netter, J.M., 2012, 'Endogeneity and the dynamics of internal corporate governance', Journal of Financial Economics 105(3), 581-606. https://doi.org/10.1016/j.jfineco.2012.03.005

Yang, T. \& Zhao, S., 2014, 'CEO duality and firm performance: Evidence from an exogenous shock to the competitive environment', Journal of Banking and Finance 49(3), 534-552. 


\section{Appendix 1}

Table 1-A1: Corporate governance models for each economic period per industry.

\begin{tabular}{|c|c|c|}
\hline Panel & Industry classification & Model specification \\
\hline \multirow[t]{8}{*}{$\begin{array}{l}\text { A: Regression equations of performance } \\
\text { measure on CG for the period 2002-2014- } \\
\text { Entire period }\end{array}$} & Financials & $\begin{array}{l}\mathrm{ROA}=-0.1357(\mathrm{BS})-2.1190(\mathrm{BI})+1.1450(\mathrm{BC})-4.8523(\mathrm{BD})+1.2480(\mathrm{LS}) \\
\text { Tobin's } \mathrm{Q}=0.0570(\mathrm{BS})-1.0815(\mathrm{BI})+0.297334(\mathrm{BC})+0.5636(\mathrm{BD})-0.6874(\mathrm{LS})\end{array}$ \\
\hline & Basic materials & $\mathrm{ROA}=-0.4035(\mathrm{BS})-9.4246(\mathrm{BI})-2.4127(\mathrm{BC})+0.1744(\mathrm{BA})+7.9258(\mathrm{BD})-8.8980(\mathrm{LS})$ \\
\hline & & Tobin's $Q=0.6755(B S)+2.9703(B I)+1.7244(B C)-0.1146(B A)$ \\
\hline & Consumer services & $\mathrm{ROA}=0.5015(\mathrm{BS})-2.9893(\mathrm{BI})+2.2661(\mathrm{BC})-0.9965(\mathrm{BA})+4.8948(\mathrm{BD})-2.3880(\mathrm{LS})$ \\
\hline & Consumer goods & $\mathrm{ROA}=0.4039(\mathrm{BS})-4.2466(\mathrm{BI})+1.0329(\mathrm{BC})+0.1687(\mathrm{BA})+16.099(\mathrm{BD})$ \\
\hline & & Tobin's $\mathrm{Q}=0.1533(\mathrm{BS})+1.1751(\mathrm{BI})+0.8907(\mathrm{BC})-0.0832(\mathrm{BA})-4.2714(\mathrm{BD})$ \\
\hline & Industrials & $\mathrm{ROA}=0.1707(\mathrm{BS})-0.9509(\mathrm{BI})-1.2120(\mathrm{BC})-0.0880(\mathrm{BA})-0.7413(\mathrm{LS})$ \\
\hline & & Tobin's $Q=0.0014(\mathrm{BS})+0.1612(\mathrm{BI})-0.0171(\mathrm{BC})+0.0037(\mathrm{BA})-0.1033(\mathrm{BD})+0.2193(\mathrm{LS})$ \\
\hline \multirow{9}{*}{$\begin{array}{l}\text { B: Regression equations of performance } \\
\text { measure on CG for the period 2005-2007 - } \\
\text { Pre-crisis period }\end{array}$} & Financials & $\mathrm{ROA}=-0.5586(\mathrm{BS})-6.3982(\mathrm{BI})+4.4321(\mathrm{BC})+0.1021(\mathrm{BA})-15.268(\mathrm{BD})+4.7332(\mathrm{LS})$ \\
\hline & Basic materials & $\mathrm{ROA}=-1.0329(\mathrm{BS})+0.5359(\mathrm{BA})+6.9678(\mathrm{BD})-13.107(\mathrm{LS})$ \\
\hline & & Tobin's Q $=0.3898(\mathrm{BS})$ \\
\hline & Consumer services & $\mathrm{ROA}=0.6181(\mathrm{BS})-2.2630(\mathrm{BI})+3.3026(\mathrm{BC})-1.8567(\mathrm{BA})+17.835(\mathrm{BD})-9.0618(\mathrm{LS})$ \\
\hline & & Tobin's $Q=0.0827(B S)+0.2169(B C)-0.1948(B A)+3.0690(B D)-0.6286(L S)$ \\
\hline & Consumer goods & Consumer goods $\mathrm{ROA}=0.6755(\mathrm{BS})-4.4861(\mathrm{BI})+0.4983(\mathrm{BA})+12.748(\mathrm{BD})-7.1772(\mathrm{LS})$ \\
\hline & & Tobin's $Q=0.1706(B S)+1.7962(B C)-0.2575(B A)-9.8164(B D)$ \\
\hline & Industrials & $\mathrm{ROA}=0.1431(\mathrm{BS})-1.5514(\mathrm{BC})+1.5559(\mathrm{LS})$ \\
\hline & & Tobin's $Q=-0.0096(B S)+0.1867(B I)+0.0277(B C)+0.1652(B D)+0.2652(L S)$ \\
\hline \multirow{8}{*}{$\begin{array}{l}\text { C: Regression equations of performance } \\
\text { measure on CG for the period 2008-2010- } \\
\text { During the crisis period }\end{array}$} & Financials & $\mathrm{ROA}=0.4090(\mathrm{BS})-11.355(\mathrm{BI})+3.8661(\mathrm{BD})+3.0567(\mathrm{LS})$ \\
\hline & & Tobin's $Q=0.1341(B C)+0.0180(B A)+0.2851(L S)$ \\
\hline & Basic materials & $\mathrm{ROA}=-3.5881(\mathrm{BS})+19.029(\mathrm{BI})+13.899(\mathrm{BD})$ \\
\hline & & Tobin's $Q=0.0252(\mathrm{BS})-1.2270(\mathrm{BI})+0.4653(\mathrm{BC})-0.1109(\mathrm{BA})+1.0601(\mathrm{BD})-0.6744(\mathrm{LS})$ \\
\hline & Consumer goods & $\mathrm{ROA}=-4.9820(\mathrm{BC})+13.998(\mathrm{BD})+10.249(\mathrm{LS})$ \\
\hline & & Tobin's $Q=0.1228(B S)+1.0213(B C)+0.1809(B A)$ \\
\hline & Industrials & $\mathrm{ROA}=-0.1097(\mathrm{BS})-4.4120(\mathrm{BI})+2.1420(\mathrm{BC})-0.4913(\mathrm{BA})+1.8578(\mathrm{BD})-1.3179(\mathrm{LS})$ \\
\hline & & Tobin's $Q=0.0067(B S)+0.1368(B C)$ \\
\hline \multirow{10}{*}{$\begin{array}{l}\text { D: Regression equations of performance } \\
\text { measure on CG for the period 2011-2013- } \\
\text { After the crisis period }\end{array}$} & Financials & $\mathrm{ROA}=0.1126(\mathrm{BS})+0.6882(\mathrm{BC})-0.2617(\mathrm{BA})-5.6558(\mathrm{BD})$ \\
\hline & & Tobin's $Q=0.0155(\mathrm{BS})-0.1213(\mathrm{BI})-0.0832(\mathrm{BC})-0.3182(\mathrm{BD})$ \\
\hline & Basic materials & $\mathrm{ROA}=0.5673(\mathrm{BS})-6.8687(\mathrm{BI})-6.8954(\mathrm{BC})+10.539(\mathrm{BD})$ \\
\hline & & Tobin's $Q=0.0327(\mathrm{BS})+0.1039(\mathrm{BI})-0.5823(\mathrm{BD})$ \\
\hline & Consumer services & $\mathrm{ROA}=0.6494(\mathrm{BS})-1.5451(\mathrm{BC})-1.1409(\mathrm{BA})+7.7731(\mathrm{BD})-2.4317(\mathrm{LS})$ \\
\hline & & Tobin's $Q=0.1394(\mathrm{BS})-0.8561(\mathrm{BI})-0.3502(\mathrm{BC})-0.2363(\mathrm{BD})-0.1999(\mathrm{LS})$ \\
\hline & Consumer goods & $\mathrm{ROA}=0.7694(\mathrm{BS})+13.327(\mathrm{BD})$ \\
\hline & & Tobin's $Q=0.7935(B I)+0.2231(B C)-0.0608(B A)+1.9226(B D)$ \\
\hline & Industrials & $\mathrm{ROA}=0.2012(\mathrm{BS})+4.8484(\mathrm{BI})-1.7845(\mathrm{BC})-0.3986(\mathrm{BA})$ \\
\hline & & Tobin's $Q=0.0049(B S)+0.5680(B I)-0.1466(B C)-0.2498(B D)$ \\
\hline
\end{tabular}

$\mathrm{N} / \mathrm{S}$, no statistical significance; ROA, return on asset; CG, corporate governance; Perf (-1), performance lag; BS, board size; BI, board independence; BC, board committees; BA, board activity; BD, board diversity; LS, leadership structure. 


\section{Appendix 2}

Table 1-A2: Descriptive statistics for the financials industry.

\begin{tabular}{|c|c|c|c|c|c|c|c|c|}
\hline Financials & Tobin's Q & ROA & BS & BI & BC & BA & BD & LS \\
\hline \multicolumn{9}{|c|}{ Entire period (2002-2014) } \\
\hline Mean & 1.2776 & 2.7203 & 11.723 & 0.4829 & 0.5653 & 5.1346 & 0.1614 & 0.9384 \\
\hline Standard deviation & 1.6087 & 13.564 & 4.9155 & 0.1633 & 0.4966 & 1.9215 & 0.1608 & 0.2407 \\
\hline Minimum & 0.0900 & -79.31 & 5.0000 & 0.0000 & 0.0000 & 0.0000 & 0.0000 & 0.0000 \\
\hline Maximum & 15.490 & 33.500 & 25.000 & 0.7857 & 1.0000 & 13.000 & 0.6666 & 1.0000 \\
\hline Observation & 260 & 260 & 260 & 260 & 260 & 260 & 260 & 260 \\
\hline \multicolumn{9}{|c|}{ Pre-financial crisis period (2005-2007) } \\
\hline Mean & 1.5446 & 2.3558 & 11.100 & 0.4597 & 0.4083 & 5.0583 & 0.1633 & 0.9000 \\
\hline Standard deviation & 2.2547 & 18.208 & 5.1112 & 0.2053 & 0.4935 & 2.1897 & 0.1655 & 0.3012 \\
\hline Minimum & 0.0900 & -79.31 & 5.0000 & 0.0000 & 0.0000 & 0.0000 & 0.0000 & 0.0000 \\
\hline Maximum & 15.490 & 33.500 & 25.000 & 0.7727 & 1.0000 & 13.000 & 0.6363 & 1.0000 \\
\hline Observation & 120 & 120 & 120 & 120 & 120 & 120 & 120 & 120 \\
\hline \multicolumn{9}{|c|}{ During the crisis period (2008-2010) } \\
\hline Mean & 0.9841 & 2.3046 & 12.416 & 0.4942 & 0.6000 & 5.1833 & 0.2123 & 0.9500 \\
\hline Minimum & 0.1100 & -25.86 & 5.0000 & 0.2500 & 0.0000 & 2.0000 & 0.0000 & 0.0000 \\
\hline Maximum & 2.7300 & 20.750 & 23.000 & 0.7857 & 1.0000 & 11.000 & 0.6666 & 1.0000 \\
\hline Observation & 60 & 60 & 60 & 60 & 60 & 60 & 60 & 60 \\
\hline \multicolumn{9}{|c|}{ After the crisis period (2011-2013) } \\
\hline Mean & 1.0972 & 3.5787 & 12.137 & 0.5092 & 0.7750 & 5.2125 & 0.1204 & 0.9875 \\
\hline Standard deviation & 0.6599 & 6.9649 & 4.4996 & 0.1075 & 0.4202 & 1.74 & 0.1204 & 0.1118 \\
\hline Minimum & 0.1200 & -9.72 & 5.0000 & 0.2857 & 0.0000 & 2.0000 & 0.0000 & 0.0000 \\
\hline Maximum & 3.6800 & 25.490 & 21.000 & 0.7777 & 1.0000 & 10.000 & 0.6000 & 1.0000 \\
\hline Observation & 80 & 80 & 80 & 80 & 80 & 80 & 80 & 80 \\
\hline
\end{tabular}

Note: Summary statistics for industrial classifications used in the regression analysis. Reported are means, with standard deviation, minimum and maximum value for the full period of time and three sub-periods, pre-crisis, during and post-crisis periods.

$\mathrm{N} / \mathrm{S}$, no statistical significance; ROA, return on asset; $\mathrm{CG}$, corporate governance; Perf (-1), performance lag; BS, board size; BI, board independence; BC, board committees; BA, board activity; BD, board diversity; LS, leadership structure.

\section{Appendix 3}

Table 1-A3: Descriptive statistics for the consumer services industry.

\begin{tabular}{|c|c|c|c|c|c|c|c|c|}
\hline Consumer services & Tobin's Q & ROA & BS & BI & $\mathrm{BC}$ & BA & BD & LS \\
\hline \multicolumn{9}{|c|}{ Entire period (2002-2014) } \\
\hline Mean & 2.0718 & 17.801 & 9.9230 & 0.4276 & 0.6315 & 4.3400 & 0.1153 & 0.9230 \\
\hline Standard deviation & 1.7814 & 13.984 & 2.7611 & 0.2403 & 0.4833 & 1.1069 & 0.1087 & 0.2670 \\
\hline Minimum & 0.0400 & -8.75 & 4.0000 & 0.0000 & 0.0000 & 2.0000 & 0.0000 & 0.0000 \\
\hline Maximum & 11.700 & 78.420 & 17.000 & 0.9090 & 1.0000 & 9.0000 & 0.4666 & 1.0000 \\
\hline Observation & 247 & 247 & 247 & 247 & 247 & 247 & 247 & 247 \\
\hline Mean & 1.5755 & 15.962 & 9.2631 & 0.3805 & 0.5087 & 4.5087 & 0.0719 & 0.9210 \\
\hline Standard deviation & 1.0837 & 10.138 & 2.7038 & 0.2679 & 0.5021 & 1.2846 & 0.0795 & 0.2708 \\
\hline Minimum & 0.0400 & -3.51 & 4.0000 & 0.0000 & 0.0000 & 2.0000 & 0.0000 & 0.0000 \\
\hline Maximum & 5.0100 & 46.180 & 15.000 & 0.8333 & 1.0000 & 9.0000 & 0.3000 & 1.0000 \\
\hline Observation & 114 & 114 & 114 & 114 & 114 & 114 & 114 & 114 \\
\hline \multicolumn{9}{|c|}{ During the crisis period (2008-2010) } \\
\hline Mean & 1.8080 & 18.788 & 10.017 & 0.4156 & 0.6842 & 4.2807 & 0.1538 & 0.9649 \\
\hline Minimum & 0.0800 & -1.82 & 5.0000 & 0.0000 & 0.0000 & 2.0000 & 0.0000 & 0.0000 \\
\hline Maximum & 5.6900 & 65.720 & 16.000 & 0.9090 & 1.0000 & 8.0000 & 0.4000 & 1.0000 \\
\hline Observation & 57 & 57 & 57 & 57 & 57 & 57 & 57 & 57 \\
\hline \multicolumn{9}{|c|}{ After the crisis period (2011-2013) } \\
\hline Mean & 3.0142 & 19.819 & 10.842 & 0.5074 & 0.7763 & 4.1315 & 0.1516 & 0.8947 \\
\hline Standard deviation & 2.4908 & 18.661 & 2.7033 & 0.1601 & 0.4194 & 0.6184 & 0.1231 & 0.3089 \\
\hline Minimum & 0.1100 & -8.75 & 6.0000 & 0.0000 & 0.0000 & 3.0000 & 0.0000 & 0.0000 \\
\hline Maximum & 11.700 & 78.420 & 17.000 & 0.8750 & 1.0000 & 6.0000 & 0.4666 & 1.0000 \\
\hline Observation & 76 & 76 & 76 & 76 & 76 & 76 & 76 & 76 \\
\hline
\end{tabular}

Note: Summary statistics for industrial classifications used in the regression analysis. Reported are means, with standard deviation, minimum and maximum value for the full period of time and three sub-periods, pre-crisis, during and post-crisis periods.

$\mathrm{N} / \mathrm{S}$, no statistical significance; ROA, return on asset; CG, corporate governance; Perf (-1), performance lag; BS, board size; BI, board independence; BC, board committees; BA, board activity; BD, board diversity; LS, leadership structure. 


\section{Appendix 4}

Table 1-A4: Descriptive statistics for the consumer goods industry.

\begin{tabular}{|c|c|c|c|c|c|c|c|c|}
\hline Consumer goods & Tobin's Q & ROA & BS & $\mathrm{BI}$ & $\mathrm{BC}$ & BA & BD & LS \\
\hline \multicolumn{9}{|c|}{ Entire period (2002-2014) } \\
\hline Mean & 2.4858 & 16.791 & 11.529 & 0.4872 & 0.6752 & 5.1965 & 0.1461 & 0.9316 \\
\hline Standard deviation & 3.4316 & 6.8161 & 3.7636 & 0.2193 & 0.4703 & 1.2610 & 0.1226 & 0.2534 \\
\hline Minimum & 0.4400 & 3.3600 & 5.0000 & 0.0000 & 0.0000 & 4.0000 & 0.0000 & 0.0000 \\
\hline Maximum & 27.130 & 36.140 & 20.000 & 0.8888 & 1.0000 & 9.0000 & 0.4285 & 1.0000 \\
\hline Observation & 117 & 117 & 117 & 117 & 117 & 117 & 117 & 117 \\
\hline \multicolumn{9}{|c|}{ Pre-financial crisis period (2005-2007) } \\
\hline Mean & 3.1151 & 15.962 & 10.611 & 0.4661 & 0.5185 & 4.8518 & 0.1361 & 0.8888 \\
\hline Standard deviation & 4.8840 & 6.4856 & 3.6570 & 0.2538 & 0.5043 & 1.1559 & 0.1178 & 0.3172 \\
\hline Minimum & 0.4400 & 3.3600 & 5.0000 & 0.0000 & 0.0000 & 4.0000 & 0.0000 & 0.0000 \\
\hline Maximum & 27.130 & 36.140 & 18.000 & 0.8750 & 1.0000 & 8.0000 & 0.3636 & 1.0000 \\
\hline Observation & 54 & 54 & 54 & 54 & 54 & 54 & 54 & 54 \\
\hline \multicolumn{9}{|c|}{ During the crisis period (2008-2010) } \\
\hline Mean & 1.5848 & 17.105 & 11.925 & 0.4647 & 0.6666 & 5.4444 & 0.2004 & 0.9259 \\
\hline Minimum & 0.4500 & 4.5100 & 5.0000 & 0.0000 & 0.0000 & 4.0000 & 0.0000 & 0.0000 \\
\hline Maximum & 3.3200 & 34.710 & 16.000 & 0.8888 & 1.0000 & 9.0000 & 0.4285 & 1.0000 \\
\hline Observation & 27 & 27 & 27 & 27 & 27 & 27 & 27 & 27 \\
\hline \multicolumn{9}{|c|}{ After the crisis period (2011-2013) } \\
\hline Mean & 2.2177 & 17.799 & 12.611 & 0.5356 & 0.9166 & 5.5277 & 0.1204 & 1.0000 \\
\hline Standard deviation & 1.0826 & 7.0018 & 4.0019 & 0.1531 & 0.2803 & 1.2980 & 0.1101 & 0.0000 \\
\hline Minimum & 0.4800 & 6.0400 & 6.0000 & 0.1666 & 0.0000 & 4.0000 & 0.0000 & 1.0000 \\
\hline Maximum & 3.8200 & 31.070 & 20.000 & 0.8333 & 1.0000 & 9.0000 & 0.4166 & 1.0000 \\
\hline Observation & 36 & 36 & 36 & 36 & 36 & 36 & 36 & 36 \\
\hline
\end{tabular}

Note: Summary statistics for industrial classifications used in the regression analysis. Reported are means, with standard deviation, minimum and maximum value for the full period of time and three sub-periods, pre-crisis, during and post-crisis periods.

$\mathrm{N} / \mathrm{S}$, no statistical significance; ROA, return on asset; CG, corporate governance; Perf (-1), performance lag; BS, board size; BI, board independence; BC, board committees; BA, board activity; BD, board diversity; LS, leadership structure.

\section{Appendix 5}

Table 1-A5: Descriptive statistics for the industrials industry.

\begin{tabular}{|c|c|c|c|c|c|c|c|c|}
\hline Industrials & Tobin's Q & ROA & BS & $\mathrm{BI}$ & BC & BA & BD & LS \\
\hline \multicolumn{9}{|c|}{ Entire period (2002-2014) } \\
\hline Mean & 1.0607 & 11.743 & 10.482 & 0.4032 & 0.7170 & 5.0868 & 0.1879 & 0.9228 \\
\hline Standard deviation & 0.6342 & 8.2713 & 4.5627 & 0.1961 & 0.4511 & 1.3966 & 0.1671 & 0.2672 \\
\hline Minimum & 0.2200 & -21.72 & 4.0000 & 0.0000 & 0.0000 & 3.0000 & 0.0000 & 0.0000 \\
\hline Maximum & 4.8700 & 51.580 & 31.000 & 0.8000 & 1.0000 & 11.000 & 0.8000 & 1.0000 \\
\hline Observation & 311 & 311 & 311 & 311 & 311 & 311 & 311 & 311 \\
\hline \multicolumn{9}{|c|}{ Pre- financial crisis period (2005-2007) } \\
\hline Mean & 1.0835 & 13.580 & 10.349 & 0.3330 & 0.5384 & 5.0629 & 0.1382 & 0.8461 \\
\hline Standard deviation & 0.6313 & 8.4703 & 5.2851 & 0.2160 & 0.5002 & 1.4785 & 0.1478 & 0.3620 \\
\hline Minimum & 0.2200 & -16.88 & 4.0000 & 0.0000 & 0.0000 & 3.0000 & 0.0000 & 0.0000 \\
\hline Maximum & 4.3800 & 46.560 & 31.000 & 0.7500 & 1.0000 & 11.000 & 0.8000 & 1.0000 \\
\hline Observation & 143 & 143 & 143 & 143 & 143 & 143 & 143 & 143 \\
\hline \multicolumn{9}{|c|}{ During the crisis period (2008-2010) } \\
\hline Mean & 1.0425 & 12.310 & 10.777 & 0.4376 & 0.7638 & 5.2777 & 0.2790 & 0.9722 \\
\hline Standard deviation & 0.7330 & 7.4528 & 4.0253 & 0.1621 & 0.4276 & 1.3450 & 0.1817 & 0.1654 \\
\hline Minimum & 0.4800 & 2.9400 & 6.0000 & 0.1666 & 0.0000 & 3.0000 & 0.0000 & 0.0000 \\
\hline Maximum & 4.8700 & 51.580 & 24.000 & 0.7500 & 1.0000 & 10.000 & 0.7500 & 1.0000 \\
\hline Observation & 72 & 72 & 72 & 72 & 72 & 72 & 72 & 72 \\
\hline \multicolumn{9}{|c|}{ After the crisis period (2011-2013) } \\
\hline Mean & 1.0404 & 8.5811 & 10.458 & 0.4820 & 0.9479 & 4.9791 & 0.1936 & 1.0000 \\
\hline Standard deviation & 0.5602 & 7.6853 & 3.7386 & 0.1468 & 0.2233 & 1.3056 & 0.1540 & 0.0000 \\
\hline Minimum & 0.2500 & -21.72 & 6.0000 & 0.2500 & 0.0000 & 3.0000 & 0.0000 & 1.0000 \\
\hline Maximum & 3.4000 & 32.410 & 24.000 & 0.8000 & 1.0000 & 10.000 & 0.7333 & 1.0000 \\
\hline Observation & 96 & 96 & 96 & 96 & 96 & 96 & 96 & 96 \\
\hline
\end{tabular}

Note: Summary statistics for industrial classifications used in the regression analysis. Reported are means, with standard deviation, minimum and maximum value for the full period of time and three sub-periods, pre-crisis, during and post-crisis periods.

$\mathrm{N} / \mathrm{S}$, no statistical significance; ROA, return on asset; CG, corporate governance; Perf (-1), performance lag; BS, board size; BI, board independence; BC, board committees; BA, board activity; BD, board diversity; LS, leadership structure. 


\section{Appendix 6}

Table 1-A6: Descriptive statistics for the basic materials industry.

\begin{tabular}{|c|c|c|c|c|c|c|c|c|}
\hline Basic materials & Tobin's Q & ROA & BS & $\mathrm{BI}$ & $\mathrm{BC}$ & BA & BD & LS \\
\hline \multicolumn{9}{|c|}{ Entire period (2002-2014) } \\
\hline Mean & 4.7651 & 9.7828 & 10.069 & 0.4326 & 0.6580 & 5.5367 & 0.1624 & 0.9653 \\
\hline Standard deviation & 28.472 & 16.300 & 2.9406 & 0.2399 & 0.4754 & 2.1238 & 0.1769 & 0.1832 \\
\hline Minimum & 0.0900 & -84.01 & 4.0000 & 0.0000 & 0.0000 & 0.0000 & 0.0000 & 0.0000 \\
\hline Maximum & 299.37 & 61.790 & 20.000 & 1.8333 & 1.0000 & 18.000 & 0.8000 & 1.0000 \\
\hline Observation & 231 & 231 & 231 & 231 & 231 & 231 & 231 & 231 \\
\hline Mean & 8.7630 & 14.477 & 9.8785 & 0.3501 & 0.5794 & 5.2523 & 0.1498 & 0.9345 \\
\hline Standard deviation & 41.555 & 13.793 & 3.4687 & 0.2678 & 0.4959 & 2.0004 & 0.1775 & 0.2484 \\
\hline Minimum & 0.0900 & -26.14 & 4.0000 & 0.0000 & 0.0000 & 0.0000 & 0.0000 & 0.0000 \\
\hline Maximum & 299.37 & 61.790 & 20.000 & 1.8333 & 1.0000 & 12.000 & 0.7000 & 1.0000 \\
\hline Observation & 107 & 107 & 107 & 107 & 107 & 107 & 107 & 107 \\
\hline \multicolumn{9}{|c|}{ During the crisis period (2008-2010) } \\
\hline Mean & 1.5866 & 9.5545 & 10.018 & 0.4594 & 0.6603 & 5.7358 & 0.2213 & 1.0000 \\
\hline Minimum & 0.3800 & -84.01 & 6.0000 & 0.0000 & 0.0000 & 3.0000 & 0.0000 & 1.0000 \\
\hline Maximum & 10.7300 & 54.890 & 15.000 & 0.8461 & 1.0000 & 18.000 & 0.8000 & 1.0000 \\
\hline Observation & 53 & 53 & 53 & 53 & 53 & 53 & 53 & 53 \\
\hline \multicolumn{9}{|c|}{ After the crisis period (2011-2013) } \\
\hline Mean & 1.1128 & 2.8781 & 10.394 & 0.5370 & 0.7746 & 5.8169 & 0.1374 & 0.9859 \\
\hline Standard deviation & 0.9426 & 12.058 & 2.5098 & 0.1748 & 0.4207 & 1.7263 & 0.1431 & 0.1186 \\
\hline Minimum & 0.2800 & -40.5 & 5.0000 & 0.2000 & 0.0000 & 1.0000 & 0.0000 & 0.0000 \\
\hline Maximum & 6.5200 & 32.070 & 16.000 & 0.9000 & 1.0000 & 11.000 & 0.7500 & 1.0000 \\
\hline Observation & 71 & 71 & 71 & 71 & 71 & 71 & 71 & 7 \\
\hline
\end{tabular}

Note: Summary statistics for industrial classifications used in the regression analysis. Reported are means, with standard deviation, minimum and maximum value for the full period of time and three sub-periods, pre-crisis, during and post-crisis periods.

$\mathrm{N} / \mathrm{S}$, no statistical significance; ROA, return on asset; CG, corporate governance; Perf (-1), performance lag; BS, board size; BI, board independence; BC, board committees; BA, board activity; BD, board diversity; LS, leadership structure. 